\title{
Relative Contributions of Ice Algae, Phytoplankton, and Benthic Microalgae to Primary Production in Nearshore Regions of the Beaufort Sea
}

\author{
RITA HORNER ${ }^{1}$ and G.C. SCHRADER ${ }^{2}$
}

\begin{abstract}
Phytoplankton, ice algae, and benthic microalgae are the three sources of primary production in the western Beaufort Sea in winter and spring. Phytoplankton levels in winter are low with chlorophyll $a$ levels near the limit of detection. Microflagellates are the most abundant organisms present in the water column along with a few diatoms. Low chlorophyll $a$, standing stock, and primary productivity continue into June when the ice breaks up. Cells are present in sea ice from the time it forms in the fall and are generally scattered throughout the ice thickness. Microflagellates are the most abundant organisms, but some diatoms, mostly pennate species, are also present. Cells concentrate in the bottom few $\mathrm{cm}$ of ice during March-April in response to increasing light levels. Growth continues until late May-early June when maximum production and standing stock occur. Benthic microalgal production was barely detectable in spring although chlorophyll $a$ levels were high, perhaps left from the previous production season. Light is apparently the major factor controlling production in the spring, with the ice algae being able to take advantage of increasing light levels early in spring. This community shades both the water column and benthos so that production in those habitats does not increase until after the ice algae disappear in early June, but the ice community may be inhibited by layers of sediment in the ice. During this study, the ice algae provided about two-thirds and the phytoplankton one-third of the spring primary production; the benthic community contribution was negligible.
\end{abstract}

Key words: western Beaufort Sea, phytopiankton, ice algae, benthic microalgae, primary productivity, chlorophyll $a$, standing stock, species present, environmental factors

\begin{abstract}
RÉSUMÉ. Le phytoplancton, les algues glaciales et les microalgues benthiques sont les trois sources de production primaire dans l'ouest de la mer de Beaufort en hiver et au printemps. Le niveau de la chlorophylle $a$ étant près de la limite de détection. Les microflagellés sont les organismes les plus abondants dans la colonne d'eau, avec quelques diatomées. Le niveau peu élevé de chlorophylle $a$, la pénurie de biomasse et une productivité primaire basse continuent jusqu'en juin, lors de la période de déglacement. Des cellules sont présentes dans la glace marine dès sa formation à l'automne et sont généralement éparpillées dans toute l'épaisseur de la glace. Les microflagellés sont les organismes les plus abondants, mais certaines diatomées, surtout les espèces pennées, sont aussi présentes. Les cellules se concentrent vers les quelques centimètres inférieurs de la glace au cours de mars et d'avril, en réponse au niveau augmentant de la lumière. La croissance continue jusqu'à la fin-mai et le début-juin, la production et la biomasse atteignant leur point maximal à ce temps. La production de microalgues benthiques pouvait à peine être discernée au printemps, bien que le niveau de chlorophylle $a$ était élevé, peut-être en tant que vestige de la saison antérieure de production. La lumière semble être le facteur principal contrôlant la production au printemps, les algues glaciales pouvant profiter de l'augmentation du niveau de la lumière durant cette saison. On trouve cette communauté dans la colonne d'eau et aussi dans le benthos, de sorte que la production dans ces habitats n'augmente qu'après la disparition des algues glaciales en début-juin, mais la communauté glaciale peut être arrêtée par des couches de sédiments dans la glace. Au cours de cette étude, les algues glaciales fournissent environ deux tiers, et le phytoplancton environ un tier de la production primaire au printemps; la contribution de la communauté benthique est négligeable.
\end{abstract}

Mots clés: l'ouest de la mer de Beaufort, phytoplancton, algues glaciales, microalgues benthiques, productivité primaire, chlorophylle $a$, biomasse présente, facteurs du milieu

Traduit pour le journal par Maurice Guibord.

\section{INTRODUCTION}

The sources of primary production that support the ecosystem in the nearshore western Beaufort Sea are not well known. Three components are apparently available: ice algae, phytoplankton, and benthic microalgae. Of these, the phytoplankton is perhaps the best known. This community, composed of diatoms, dinoflagellates, and microflagellates, occurs in the water column from about the time of ice breakup through the summer.

The ice algal community lives in and on the underside of sea ice and is present primarily during the spring, usually April through early June, but cells are also present in the ice throughout the winter and there are reports of a layer of healthy, active cells in the ice in November (Hsiao, 1980; Schell, pers. comm.). This community is composed primarily of pennate diatoms and microflagellates, but centric diatoms and dinoflagellates may also be present, usually in low numbers.
The benthic microalgae, primarily pennate diatoms, live on and among sand grains on the sea floor. This community is probably present in summer, although solitary, motile pennate diatoms may be present in spring, sometimes forming brownish patches in the lee of sediment ripples. In the Chukchi Sea, a dense mat of filamentous diatoms may form in some areas in summer (Matheke and Horner, 1974). The benthic microalgal community has not been studied in the nearshore Beaufort Sea in summer.

Our objectives were to assess the winter density distribution and environmental requirements of phytoplankton in the nearshore Beaufort Sea and to undertake an integrated study of ice algae, phytoplankton, and benthic microalgae production to provide comparisons among these habitats and allow us to determine the relative importance of these communities during the spring growing season. Sampling was done for 3-4 day periods in November 1978 and February, March, and May 1979 in Stefansson Sound 
$\left(70^{\circ} 19^{\prime} \mathrm{N}, 147^{\circ} 34.4^{\prime} \mathrm{W}\right)$, and intensively from early April through mid-June 1980 in the Beaufort Sea just north of Narwhal Island $\left(70^{\circ} 24^{\prime} \mathrm{N}, 147^{\circ} 31.1^{\prime} \mathrm{W}\right)$ (Fig. 1).

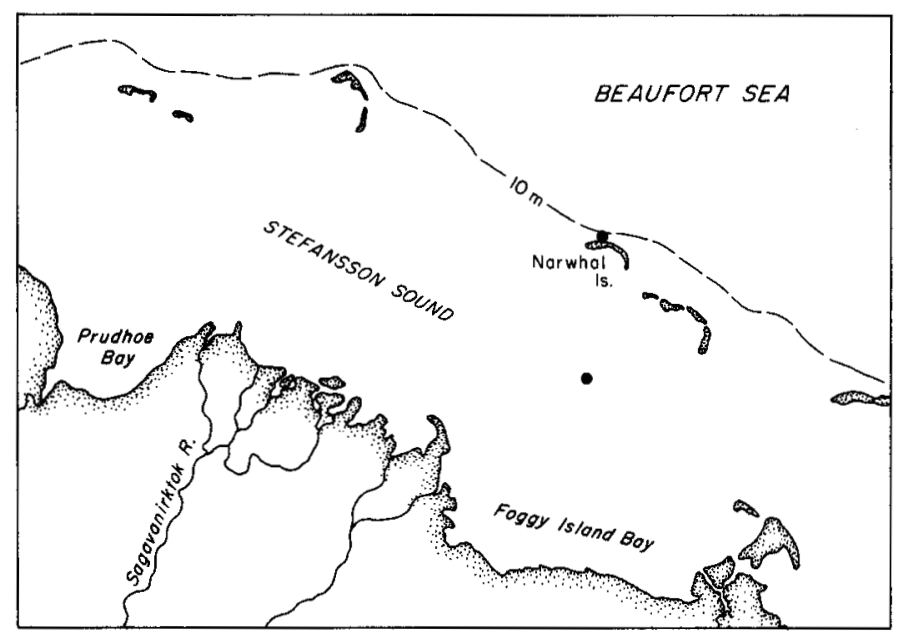

FIG. 1. Location of study sites in Stefansson Sound (1978-1979) and off Narwhal Island (spring 1980).

\section{METHODS}

During this study, we have determined primary productivity, plant pigments, standing stock (cell numbers), and species composition of the ice algae, phytoplankton, and benthic microalgae; we have also measured environmental parameters including light, temperature, salinity, nutrient concentrations, and snow cover, but not all parameters were determined during each sampling period. We include an extensive description of our methods particularly for the ice algae because of the difficulties encountered in studying this community and because the wide variety of methods used in the past has made comparisons between areas difficult.

\section{Stefansson Sound}

Water samples from near the bottom of the ice $(0 \mathrm{~m})$ and from near the sea floor $(4.5 \mathrm{~m})$ were collected by lowering plastic water sampling bottles through holes cut in the ice. Subsamples for phytoplankton standing stock determinations were poured into $250-\mathrm{ml}$ glass jars and immediately preserved with $10 \mathrm{ml} 4 \%$ formaldehyde buffered with sodium acetate. The remainder of the sample was kept cool until it could be filtered on shore. One to two liters of water were filtered through $47 \mathrm{~mm}, 0.45 \mu \mathrm{m}$ Millipore filters for plant pigment determinations. Three drops of a saturated solution of $\mathrm{MgCO}_{3}$ were added near the end of the filtration process and the filter tower was rinsed with filtered seawater. The filters were folded and frozen in a desiccator.

In May 1979, primary productivity was determined on ice and water samples. Subsamples of water in $60-\mathrm{ml}$ glass reagent bottles, two light and one dark bottle for each depth, were inoculated with ca. $5 \mu \mathrm{Ci} \mathrm{Na}_{2} \mathrm{H}^{14} \mathrm{CO}_{3}$ solution. The samples were incubated in situ for 3-4 hr in clear plastic tubes suspended from the bottom of the ice. Dark bottles were incubated in a darkened plastic tube suspended at $0 \mathrm{~m}$. Following incubation and retrieval, the samples were placed in a black box in an ice chest until they were filtered on shore. Primary productivity of the ice algae was measured using a combination incubation chamber-sampler (Clasby et al., 1973). Two light and one dark chamber were placed in the ice by SCUBA divers and the chambers were inoculated with ca. $5 \mu \mathrm{Ci} \mathrm{Na}{ }_{2} \mathrm{H}^{14} \mathrm{CO}_{3}$ solution. The dark chamber was removed from the ice immediately after inoculation, capped, and suspended from an ice piton attached to the underside of the ice. After a 3-4 $\mathrm{hr}$ incubation period, a heavy metal spatula was used to chip away the ice from around the chamber and sever the top of the core. The sample was retained in the chamber by a core cap. The ice cores were transferred to $250-\mathrm{ml}$ glass jars and preserved with $5 \mathrm{ml} 4 \%$ buffered formaldehyde to prevent further uptake of isotope by the algae.

Additional ice cores were collected for standing stock, plant pigment, nutrient, and salinity determinations. All cores were transferred to $250-\mathrm{ml}$ glass jars and the standing stock sample was immediately preserved with $5 \mathrm{ml} 4 \%$ buffered formaldehyde. The other cores were placed in an ice chest for return to shore.

At the shore laboratory, the water and ice productivity samples were filtered through $25 \mathrm{~mm}, 0.45 \mu \mathrm{m}$ Millipore filters, rinsed with $5 \mathrm{ml} 0.01 \mathrm{~N} \mathrm{HCl}$ and $5 \mathrm{ml}$ filtered seawater, and placed in labeled scintillation vials. Water and ice samples to be used for plant pigment determinations were filtered as above. Before the $\mathrm{MgCO}_{3}$ and filtered seawater were added, filtration was stopped and the filtrate was poured into two $125 \mathrm{ml}$ polyethylene bottles for nutrient and salinity determinations. The nutrient sample was frozen immediately.

\section{Narwhal Island}

Water samples were collected as previously described, except that depths were just below the ice $(0 \mathrm{~m})$ and $1 \mathrm{~m}$ above the bottom $(7 \mathrm{~m})$. Primary productivity experiments were done as in May 1979. The remainder of the water samples, usually $2 l$, was kept in a darkened ice chest and returned to the shore laboratory where it was thoroughly shaken. We preserved $250 \mathrm{ml}$ with $10 \mathrm{ml} 4 \%$ buffed formaldehyde for standing stock analysis. One liter of water from each sampling depth was filtered through a $47 \mathrm{~mm}, 0.45$ $\mu \mathrm{m}$ Millipore filter for plant pigment, nutrient, and salinity analysis as described above.

The ice algae were collected using a re-designed samplerincubation chamber (Schrader et al., 1982). Following incubation, the samples were immediately transferred to $250-\mathrm{ml}$ opaque glass jars and two drops of $0.4 \% \mathrm{HgCl}_{2}$ were added to kill the cells and prevent further uptake of the isotope. Four additional ice cores were collected for determination of standing stock, plant pigments, nutrient concentrations, and salinity. All cores were transferred to 
250-ml glass jars and kept in the dark in an ice chest until processing on shore, usually within 2-3 hr. The additional cores were taken after the ${ }^{14} \mathrm{C}$ incubation period to minimize the time between collecting and processing.

Primary productivity and plant pigment cores were filtered as before except that animals $>1 \mathrm{~mm}$ were removed from the filter. The ice core to be used for standing stock determination was preserved with $10 \mathrm{ml} 4 \%$ formaldehyde buffered with sodium acetate.

Phytoplankton and ice algae primary productivity samples were counted using a Packard Tri-Carb Liquid Scintillation Spectrometer (Packard Instrument Company, Inc.,
Downers Grove, IL) with Aquasol (New England Nuclear, Boston, MA) as the scintillation cocktail. Carbon uptake was calculated using the equation in Strickland and Parsons (1972). Chlorophyll $a$ and pheopigments were determined using the fluorometric technique (Strickland and Parsons, 1972). Nutrient samples were analyzed using autoanalyzer techniques; salinity was determined with a salinity bridge (Pavlou, 1972).

Standing stock samples were analyzed using a Zeiss phase-contrast inverted microscope and Zeiss counting chambers following the method of Utermöhl (1931). In addition, portions of some ice algae samples were acid-

TABLE 1. Standing stock, plant pigment, primary productivity, nutrient, and salinity data from Stefansson Sound, Nov 1978-May 1979

\begin{tabular}{|c|c|c|c|c|c|c|c|c|c|c|c|}
\hline \multirow[b]{2}{*}{ Date } & \multirow[b]{2}{*}{$\begin{array}{c}\text { Depth } \\
\text { (m) }\end{array}$} & \multirow[b]{2}{*}{$\begin{array}{l}\text { Standing Stock } \\
\left(\text { cells } \cdot l^{-1} \times 10^{4}\right)\end{array}$} & \multirow[b]{2}{*}{$\begin{array}{c}\mathrm{Chl} a \\
\left(\mathrm{mg} \cdot \mathrm{m}^{-3}\right)\end{array}$} & \multirow[b]{2}{*}{$\begin{array}{c}\text { Pheo } \\
\left(\mathrm{mg} \cdot \mathrm{m}^{-3}\right)\end{array}$} & \multirow[b]{2}{*}{$\begin{array}{c}\text { Prim Prod } \\
\left(\mathrm{mg} \mathrm{C}^{-3} \cdot \mathrm{m}^{-3} \cdot \mathrm{hr}^{-1}\right)\end{array}$} & \multirow[b]{2}{*}{$\mathrm{NO}_{3}$} & \multicolumn{4}{|c|}{ Nutrient Concentrations } & \multirow[b]{2}{*}{$\begin{array}{c}\text { Salinity } \\
(\%)\end{array}$} \\
\hline & & & & & & & $\mathrm{NO}_{2}$ & $\underset{\left(\mu \mathrm{g}-\mathrm{at} \cdot l^{-1}\right)}{\mathrm{NH}_{3}}$ & $\mathrm{PO}_{4}$ & $\mathrm{SiO}_{4}$ & \\
\hline \multirow[t]{2}{*}{8 Nov 78} & $\mathbf{0}$ & 2.6 & 0.06 & 0.07 & & & & & & & \\
\hline & 4 & 1.4 & & & & & & & & & \\
\hline \multirow[t]{2}{*}{9} & 0 & 2.4 & 0.02 & 0.12 & & & & & & & \\
\hline & 4 & 1.8 & 0.02 & 0.12 & & & & & & & \\
\hline \multirow[t]{2}{*}{10} & $\mathbf{0}$ & & 0.06 & 0.06 & & & & & & & \\
\hline & 4 & & 0.06 & 0.08 & & & & & & & \\
\hline \multirow[t]{2}{*}{11} & $\mathbf{0}$ & & 0.05 & 0.04 & & & & & & & \\
\hline & 4 & & 0.05 & 0.05 & & & & & & & \\
\hline \multirow[t]{2}{*}{12} & 0 & & 0.06 & 0.07 & & & & & & & \\
\hline & 4 & & 0.04 & 0.06 & & & & & & & \\
\hline \multirow[t]{2}{*}{13} & $\mathbf{0}$ & & 0.06 & 0.05 & & & & & & & \\
\hline & 4 & & 0.04 & 0.06 & & & & & & & \\
\hline \multirow[t]{2}{*}{14} & $\mathbf{0}$ & & 0.07 & 0.05 & & & & & & & \\
\hline & 4 & & 0.04 & 0.05 & & & & & & & \\
\hline \multirow[t]{2}{*}{15} & $\mathbf{0}$ & & 0.05 & 0.06 & & & & & & & \\
\hline & 4 & & 0.06 & 0.06 & & & & & & & \\
\hline \multirow[t]{2}{*}{16} & 0 & 4.6 & 0.06 & 0.05 & & & & & & & \\
\hline & 4 & 4.6 & 0.06 & 0.05 & & & & & & & \\
\hline \multirow[t]{2}{*}{15 Feb 79} & $\mathbf{0}$ & 3.6 & 0.02 & 0.07 & & & & & & & \\
\hline & 4 & 2.2 & 0.01 & 0.04 & & & & & & & \\
\hline \multirow[t]{2}{*}{$12 \operatorname{Mar} 79$} & 0 & 4.6 & 0.01 & 0.03 & & & & & & & \\
\hline & 4 & 3.4 & 0.00 & 0.02 & & & & & & & \\
\hline \multirow[t]{2}{*}{13} & 0 & & 0.00 & 0.02 & & & & & & & \\
\hline & 4 & & 0.01 & 0.03 & & & & & & & \\
\hline \multirow[t]{2}{*}{14} & ice* & $1.5 \times 10^{2}$ & 0.00 & 0.03 & & & & & & & \\
\hline & 0 & & 0.01 & 0.03 & & & & & & & \\
\hline 15 & 0 & & 0.01 & 0.03 & & & & & & & \\
\hline & 4 & & 0.01 & 0.03 & & & & & & & \\
\hline 16 & 0 & 6.0 & 0.01 & 0.03 & & & & & & & \\
\hline & 4 & 8.2 & 0.01 & 0.03 & & & & & & & \\
\hline 15 May 79 & ice & & 2.87 & 4.32 & 1.50 & 1.35 & 0.14 & 2.68 & 1.38 & 19.90 & \\
\hline 18 & ice & & 2.70 & 3.36 & 1.42 & 1.19 & 0.06 & 2.85 & 0.74 & 20.62 & 15.3 \\
\hline & 0 & 16.2 & 0.42 & 1.13 & 0.16 & 1.55 & 0.04 & 1.07 & 0.20 & 24.06 & 18.3 \\
\hline & 4 & 3.8 & 0.17 & 0.24 & 0.12 & 4.69 & 0.17 & 0.84 & 1.42 & 13.34 & 35.2 \\
\hline 19 & ice & & 2.53 & 2.83 & 0.31 & 1.24 & 0.05 & 1.87 & 0.50 & 21.02 & 15.9 \\
\hline & 0 & & 0.67 & 1.05 & 0.16 & 1.57 & 0.16 & 1.68 & 0.39 & 26.27 & 18.3 \\
\hline & 4 & & 0.24 & 0.43 & 0.80 & 4.72 & 0.06 & 0.24 & 0.95 & 13.23 & 35.2 \\
\hline 20 & ice & 8.9 & 3.01 & 1.99 & 1.42 & 0.76 & 0.06 & 2.66 & 0.46 & 20.56 & 14.1 \\
\hline & 0 & 20.8 & 1.19 & 0.89 & 0.11 & 1.01 & 0.05 & 1.04 & 0.24 & 24.53 & 16.6 \\
\hline & 4 & 3.6 & 0.23 & 0.33 & 0.26 & 4.46 & 0.16 & 0.79 & 0.91 & 13.43 & 34.8 \\
\hline
\end{tabular}

*Standing stock, plant pigments, and primary productivity from the ice are given on a $\mathrm{m}^{-2}$ basis. 
TABLE 2.Standing stock, plant pigment, primary productivity, nutrient, salinity, and light data from Narwhal Island, Apr-Jun 1980




TABLE 2 continued

\begin{tabular}{|c|c|c|c|c|c|c|c|c|c|c|c|c|}
\hline \multirow[b]{2}{*}{ Date } & \multirow[b]{2}{*}{$\begin{array}{c}\text { Depth } \\
\text { (m) }\end{array}$} & \multirow[b]{2}{*}{$\begin{array}{c}\text { Light } \\
\text { (\% sfe) }\end{array}$} & \multirow[b]{2}{*}{$\begin{array}{l}\text { Standing Stock } t \\
\left(\text { cells } \cdot \mathrm{m}^{-2}\right)\end{array}$} & \multirow[b]{2}{*}{$\underset{\left(\mathrm{mg} \cdot \mathrm{m}^{-3}\right)}{\mathrm{Chl} a}$} & \multirow[b]{2}{*}{$\begin{array}{c}\text { Pheo } \\
\left(\mathbf{m g} \cdot \mathbf{m}^{-3}\right)\end{array}$} & \multirow[b]{2}{*}{$\begin{array}{c}\text { Prim Prod } \\
\left(\mathrm{mg} \mathrm{C} \cdot \mathrm{m}^{-3} \cdot \mathrm{hr}^{-1}\right)\end{array}$} & \multicolumn{6}{|c|}{ Nutrient Concentrations } \\
\hline & & & & & & & $\mathrm{NO}_{3}$ & $\mathrm{NO}_{2}$ & $\begin{array}{c}\mathrm{NH}_{3} \\
\left(\mu \mathrm{g}-\mathrm{at} \cdot l^{-1}\right)\end{array}$ & $\mathrm{PO}_{4}$ & $\mathrm{SiO}_{4}$ & $\begin{array}{c}\text { Salinity } \\
(\% \circ)\end{array}$ \\
\hline & sed & & & 0.7 & 1.0 & - & & & & & & \\
\hline \multirow[t]{4}{*}{22} & ice & 1.08 & $7.9 \times 10^{8}$ & 14.4 & 1.5 & 0.71 & 10.7 & 0.19 & 0.77 & 1.36 & 19 & 31.60 \\
\hline & $\mathbf{0}$ & 0.72 & $1.8 \times 10^{8}$ & 0.2 & 0.1 & 0.21 & 9.0 & 0.08 & 0.04 & 1.40 & 22 & 33.74 \\
\hline & 7 & & & 0.1 & 0.1 & 0.09 & 9.6 & 0.10 & 0.00 & 1.42 & 23 & 34.52 \\
\hline & sed & & $3.0 \times 10^{9}$ & 14.2 & 7.7 & - & & & & & & \\
\hline \multirow[t]{4}{*}{24} & ice & & $8.2 \times 10^{8}$ & 11.1 & 0.3 & 0.55 & 14.0 & 0.28 & 1.03 & 2.06 & 21 & 31.02 \\
\hline & 0 & & $8.1 \times 10^{7}$ & 0.4 & 0.1 & 0.13 & 8.9 & 0.08 & 0.02 & 1.60 & 22 & 33.63 \\
\hline & 7 & & & 0.1 & 0.1 & 0.13 & 9.6 & 0.09 & 0.02 & 1.50 & 23 & 34.33 \\
\hline & sed & & & 7.2 & 5.2 & - & & & & & & \\
\hline \multirow[t]{4}{*}{26} & ice & 0.87 & $1.0 \times 10^{9}$ & 13.5 & 1.5 & 0.38 & 16.6 & 0.20 & 1.52 & 1.89 & 22 & 30.05 \\
\hline & 0 & 0.36 & $5.3 \times 10^{7}$ & 0.8 & 0.2 & 0.09 & 8.9 & 0.20 & 0.00 & 4.36 & 22 & 33.60 \\
\hline & 7 & 0.20 & & 0.2 & 0.1 & - & 9.3 & 0.08 & 0.00 & 3.94 & 23 & 33.88 \\
\hline & sed & & & 6.1 & 2.9 & - & & & & & & \\
\hline \multirow[t]{4}{*}{29} & ice & 1.74 & $8.5 \times 10^{8}$ & 12.7 & 1.6 & 2.64 & 9.6 & 0.13 & 0.54 & 1.46 & 20 & 32.32 \\
\hline & $\mathbf{0}$ & 0.81 & $7.0 \times 10^{7}$ & 0.2 & 0.1 & 0.06 & 9.1 & 0.09 & 0.00 & 1.36 & 23 & 34.12 \\
\hline & 7 & 0.59 & & 0.1 & 0.1 & - & 9.5 & 0.09 & 0.00 & 1.40 & 23 & 34.38 \\
\hline & sed & & $4.0 \times 10^{8}$ & 0.9 & 0.8 & 0.02 & & & & & & \\
\hline \multirow[t]{4}{*}{31} & ice & 2.00 & $1.2 \times 10^{9}$ & 26.5 & 3.2 & 0.77 & 17.4 & 0.32 & 1.20 & 1.53 & 20 & 32.88 \\
\hline & 0 & 0.94 & $6.3 \times 10^{7}$ & 0.5 & 0.2 & 0.04 & 9.1 & 0.09 & 0.03 & 1.41 & 23 & 34.21 \\
\hline & 7 & 0.27 & & 0.1 & 0.1 & - & 9.4 & 0.09 & 0.00 & 1.29 & 23 & 34.35 \\
\hline & sed & & & 16.5 & 6.0 & $<0.01$ & & & & & & \\
\hline \multirow[t]{4}{*}{2 Jun } & ice & 1.86 & $8.5 \times 10^{8}$ & 20.4 & 3.4 & 0.36 & 18.0 & 0.17 & 0.87 & 1.68 & 22 & 31.52 \\
\hline & 0 & 0.50 & $6.3 \times 10^{7}$ & 0.3 & 0.2 & 0.05 & 8.7 & 0.09 & 0.03 & 1.33 & 22 & 34.03 \\
\hline & 7 & 0.19 & & 0.1 & 0.1 & 0.03 & 9.7 & 0.09 & 0.01 & 1.27 & 23 & 34.50 \\
\hline & sed & & & 10.9 & 5.6 & 0.02 & & & & & & \\
\hline \multirow[t]{4}{*}{5} & ice & 1.30 & $6.7 \times 10^{8}$ & 12.0 & 2.0 & 0.46 & 16.1 & 0.18 & 1.08 & 2.28 & 22 & 31.66 \\
\hline & 0 & 0.56 & $1.5 \times 10^{8}$ & & & 0.07 & 8.2 & 0.09 & 0.11 & 1.11 & 21 & 33.66 \\
\hline & 7 & 0.14 & & 0.2 & 0.1 & 0.16 & 10.4 & 0.10 & 0.07 & 16.95 & 25 & 34.78 \\
\hline & sed & & $8.0 \times 10^{8}$ & 28.7 & 6.6 & $<0.01$ & & & & & & \\
\hline \multirow[t]{4}{*}{7} & ice & 4.01 & $6.6 \times 10^{8}$ & 17.2 & 2.7 & 2.60 & 9.7 & 0.22 & 1.85 & 1.77 & 22 & 31.21 \\
\hline & $\mathbf{0}$ & 2.65 & $2.3 \times 10^{8}$ & 0.7 & 0.7 & 0.42 & 8.0 & 0.10 & 0.43 & 1.38 & 21 & 32.91 \\
\hline & 7 & 0.33 & & 0.2 & 0.2 & - & 10.4 & 0.09 & 0.00 & 1.38 & 24 & 34.73 \\
\hline & sed & & & 17.0 & 7.9 & - & & & & & & \\
\hline \multirow[t]{4}{*}{9} & ice & 1.83 & $1.1 \times 10^{9}$ & 18.0 & 2.9 & 1.69 & 7.8 & 0.21 & 4.33 & 1.36 & 21 & 26.38 \\
\hline & 0 & 0.41 & $9.5 \times 10^{7}$ & 1.0 & 1.0 & - & 8.1 & 0.09 & 0.64 & 1.27 & 20 & 28.19 \\
\hline & 7 & 0.24 & & 0.1 & 0.1 & - & 10.2 & 0.09 & 0.00 & 1.22 & 23 & 34.54 \\
\hline & sed & & & 4.8 & 2.7 & 0.01 & & & & & & \\
\hline \multirow[t]{4}{*}{11} & ice & 2.80 & $7.0 \times 10^{6}$ & 0.1 & 0.0 & & 7.1 & 0.09 & 2.26 & 2.86 & 21 & 16.39 \\
\hline & 0 & 1.51 & $6.7 \times 10^{8}$ & 1.4 & 0.3 & 0.01 & 9.9 & 0.09 & 0.64 & 2.62 & 23 & 24.09 \\
\hline & 7 & 0.23 & & 0.5 & 0.1 & 0.01 & 6.8 & 0.16 & 0.11 & 0.88 & 23 & 33.84 \\
\hline & sed & & & 12.2 & 6.3 & - & & & & & & \\
\hline
\end{tabular}

* Plant pigment and primary productivity data for the ice and sediments are given on a $\mathrm{m}^{-2}$ basis.

$\dagger$ Integrated standing stock for the water column is given at $\mathbf{0} \mathbf{~ m}$.

- Dark bottle uptake higher than light bottle uptake. 


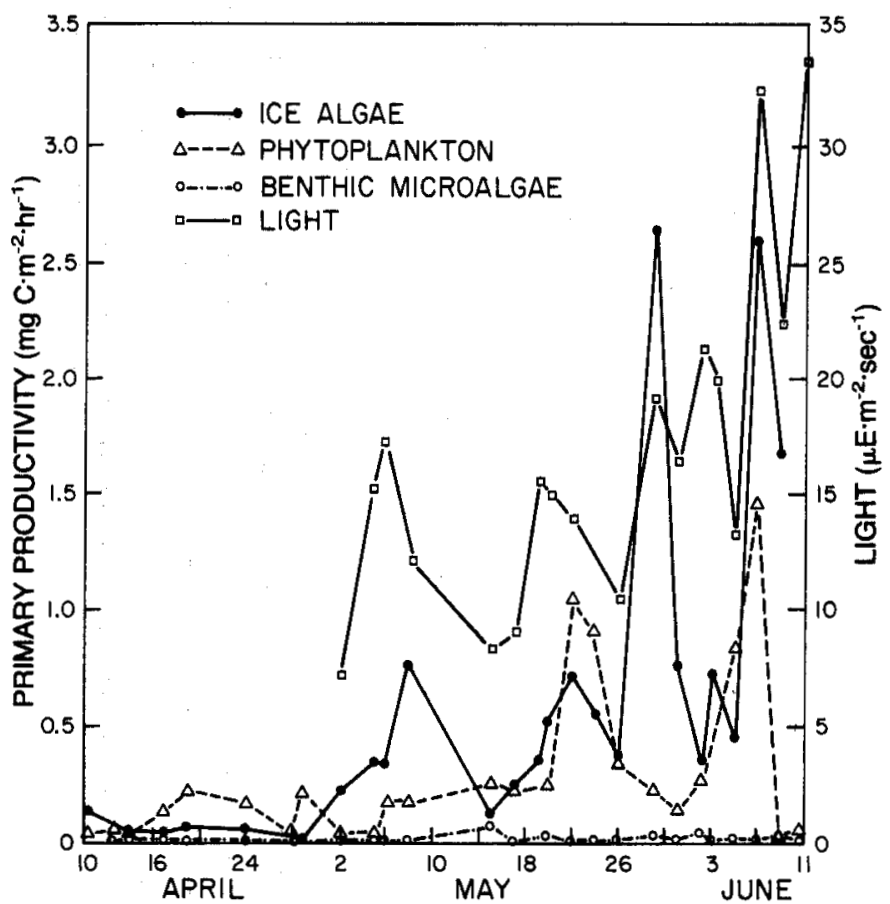

FIG. 2. Primary productivity $\left(\mathrm{mg} \mathrm{C} \cdot \mathrm{m}^{-2} \cdot \mathrm{hr}^{-1}\right)$ and incident light intensity $\left(\mu \mathrm{E} \cdot \mathrm{m}^{-2} \cdot \mathrm{sec}^{-1}\right)$, spring 1980 . Productivity of the water column was calculated by integrating productivity at 0 and $7 \mathrm{~m}$.

cleaned and permanently mounted in euparol to aid in identification.

Primary productivity and standing stock of the benthic microalgal community were studied using field and laboratory techniques described by Matheke and Horner (1974), except that carbon uptake was determined using the wet combustion technique described by Atlas and Hubbard (1974).

Light intensity was measured with an underwater quantum sensor and a quantum radiometer-photometer (Models LI-192S and LI-185A, LI-COR, Inc., Lincoln, NE) that measure light intensity in the photosynthetically active 400-700 nm wave band. Submarine light was measured immediately after placement of the ${ }^{14} \mathrm{C}$ incubation chambers and just prior to their retrieval. With the sensor directed upward, light was measured directly beneath the ice, before and after removal of the ice algal layer. Light reaching the benthos was measured near the bottom, directly above the ${ }^{14} \mathrm{C}$ incubation chambers. Ambient light outside the dive shelter was determined with the sensor held vertically ca. $2 \mathrm{~m}$ above the snow surface.

We also ran a series of transects through a semi-permanent snow drift and through the area where most of the ice samples were collected to assess the effect of snow depth on light penetration and algal growth. A line marked at $0.5 \mathrm{~m}$ intervals was anchored to a reference post placed through the ice and visible from both the surface and underside of the ice. The surface light intensity was recorded and snow depth measured at $0.5-1.0 \mathrm{~m}$ intervals for a distance of $25 \mathrm{~m}$. Immediately after the surface transect, the line was secured to the reference post under the ice and the light intensity was measured at the same points before and after removal of the ice algal layer.

\section{RESULTS}

\section{Stefansson Sound}

Phytoplankton levels in Stefansson Sound were low during the winter period (Table 1). Unidentified flagellates, mostly $<6 \mu \mathrm{m}$ in diameter, were the most common organisms present in November, February and March. A few diatoms, including spores of Chaetoceros spp. and cells of Navicula spp. and Nitzschia spp., were also present. The diatoms contained chloroplasts, but did not appear to be healthy. Chlorophyll $a$ concentrations were barely detectable. More diatoms were present in March, but chlorophyll $a$ levels were still low.

By May, more diatom cells were present in the water column, including species of Chaetoceros, Cylindrotheca, Navicula, and Nitzschia. These were mostly pennate species and were probably released from the ice as it began to disintegrate. Unidentified small flagellates were abundant. Unidentified species of Protoperidinium and other unidentified dinoflagellates were present in low numbers. Chlorophyll $a$ concentrations increased to near $1 \mathrm{mg} \cdot \mathrm{m}^{-3}$.

An ice core contained $>23 \times 10^{6}$ cells $\cdot l^{-1}$, with the diatoms Nitzschia frigida and $N$. cylindrus comprising about $50 \%$ of the population. Unidentified small flagellates were also abundant, as were unidentified cryptomonads; the euglenoids Eutreptiella sp. and Urceolus sp.; and unidentified dinoflagellates, including Protoperidinium spp. Chytridiaceous fungi were found to be parasitizing some of the pennate diatoms. Chlorophyll $a$ in the ice was near $2.7 \mathrm{mg} \cdot \mathrm{m}^{-2}$.

Primary productivity in the water column was low, averaging ca. $0.15 \mathrm{mg} \mathrm{C} \cdot \mathrm{m}^{-3} \cdot \mathrm{hr}^{-1}$. In the ice, primary productivity was near $1.5 \mathrm{mg} \mathrm{C} \cdot \mathrm{m}^{-2} \cdot \mathrm{hr}^{-1}$.

\section{Narwhal Island}

Ice algal productivity was $<0.2 \mathrm{mg} \mathrm{C} \cdot \mathrm{m}^{-2} \cdot \mathrm{hr}^{-1}$ during April (Fig. 2, Table 2), but increased to $0.8 \mathrm{mg} \mathrm{C} \cdot \mathrm{m}^{-2} \cdot \mathrm{hr}^{-1}$ during the first week in May when submarine light levels increased. After a week of stormy weather with fog and blowing snow, light dropped to one-half the previous level and productivity to ca. $0.1 \mathrm{mg} \mathrm{C} \cdot \mathrm{m}^{-2} \cdot \mathrm{hr}^{-1}$, increasing to $2.6 \mathrm{mg} \mathrm{C} \cdot \mathrm{m}^{-2} \cdot \mathrm{hr}^{-1}$ by the end of May in response to increased light. Snow was completely gone from the surface of the ice, and overflow from the Sagavanirktok River was first noticed by the divers. Two days later, the soft bottom layer of ice containing the ice algae had begun to dissociate from the ice forming a slush layer loosely associated with the undersurface of the ice. Small pieces of the slush layer clouded the water column. Another peak in productivity occurred in early June, and by mid-June the underside of the ice was eroding and the ice algal layer was no longer visible. 
Water column productivity was $<0.2 \mathrm{mg} \mathrm{C} \cdot \mathrm{m}^{-3} \cdot \mathrm{hr}^{-1}$ during April and the first half of May, but increased during late May and early June. Two productivity peaks were evident, 22 May and 7 June, coinciding with periods of high ice algal productivity. The highest water column productivity occurred on 7 June and probably resulted from the disintegrating ice algal layer. Productivity in the water column was primarily at $0 \mathrm{~m}$, with productivity at $7 \mathrm{~m}$ near the limit of detection throughout the sampling period. Surface and $7 \mathrm{~m}$ water column productivity were integrated for comparison with ice algal and benthic microalgal communities (Fig. 2).

Benthic productivity remained near the limit of detection, ca. $0.01 \mathrm{mg} \mathrm{C} \cdot \mathrm{m}^{-2} \cdot \mathrm{hr}^{-1}$, throughout the study. Light reaching the benthos was ca. $0.2 \%$ of surface values and this probably limited growth. Although light levels at the ice-water interface increased as the snow melted, shading from the growing ice algal layer prevented an increase in light at depth.

Total productivity for the three communities during the course of the sampling period was calculated by multiplying the hourly rate by the day length in hours and integrating the daily rates over the study period. The ice algal community contributed $688 \mathrm{mg} \mathrm{C} \cdot \mathrm{m}^{-2}$, or ca. two-thirds of the measured primary production; the phytoplankton $380 \mathrm{mg} \mathrm{C} \cdot \mathrm{m}^{-2}$, or one-third; and the benthic community, a negligible $12 \mathrm{mg} \mathrm{C} \cdot \mathrm{m}^{-2}$.

Chlorophyll $a$ in the ice algae followed a pattern similar to that shown for primary productivity. Levels were relatively low during April, ca. $1 \mathrm{mg} \cdot \mathrm{m}^{-2}$, increasing to $>26 \mathrm{mg} \cdot \mathrm{m}^{-2}$ during the latter part of May and dropping to near zero by the end of the bloom period in mid-June (Fig. 3).

Pigment concentrations in the water column remained low throughout most of the study period, rising slightly near the end of the ice algal bloom. Chlorophyll $a$ concentrations at $7 \mathrm{~m}$ were fairly constant, ranging from $<0.1-0.4$ $\mathrm{mg} \cdot \mathrm{m}^{-3}$. The same low levels occurred at $0 \mathrm{~m}$ during April and early May, but increased in late May and early June with a peak of $1.4 \mathrm{mg} \cdot \mathrm{m}^{-3}$ on 11 June, reflecting the large quantity of ice algae dropping from the undersurface of the ice.

Chlorophyll $a$ concentrations in the sediments were comparable to those found on the undersurface of the ice, with both communities increasing in late May-early June. During April, however, benthic chlorophyll $a$ levels were ca. five times greater than those found in the ice algal community. We think it likely that the high chlorophyll is from benthic microalgae remaining in the sediments from the previous benthic production season, because pheopigments were high and primary productivity levels in the sediments were negligible, suggesting that cells in the sediments were not growing.

Small, unidentified flagellates, mostly $<6 \mu \mathrm{m}$ in diameter, accounted for ca. $50 \%$ of the cells in the ice algal community (Fig. 4). The remainder of the population was

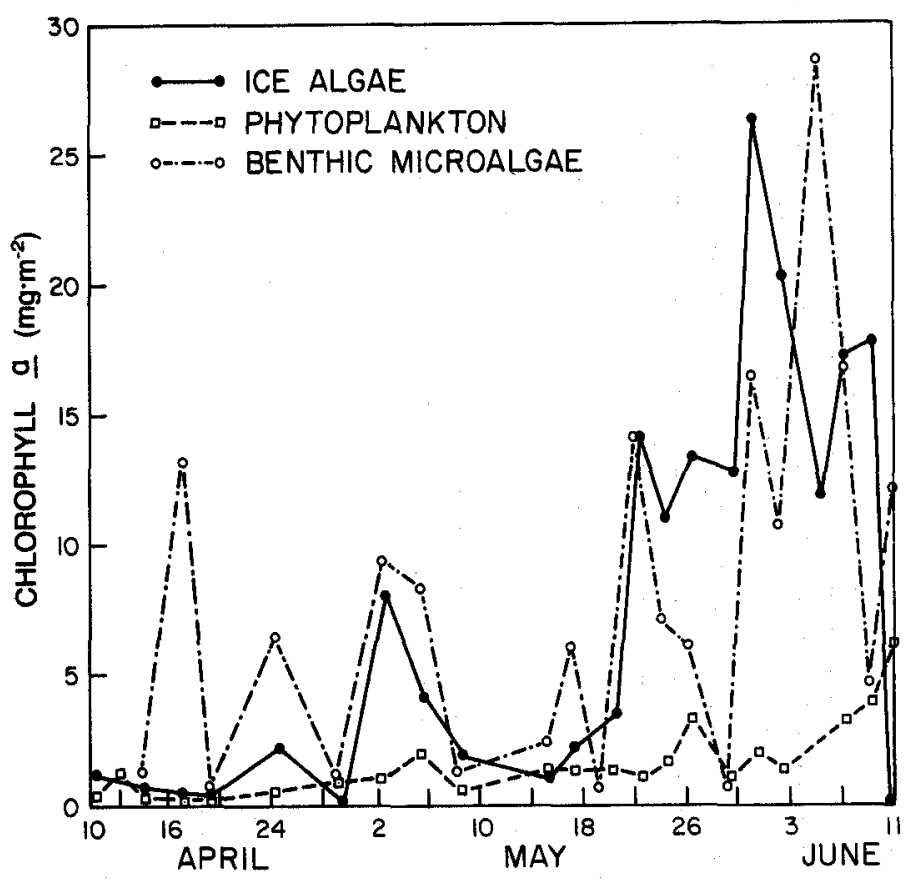

FIG. 3. Chlorophyll $a\left(\mathrm{mg} \cdot \mathrm{m}^{-2}\right)$, spring 1980 . Chlorophyll $a$ of the ice algae is the average of three replicate cores; chlorophyll $a$ of the benthic microalgae is from one core; chlorophyll $a$ of the water column was calculated by integrating values from 0 and $7 \mathrm{~m}$.

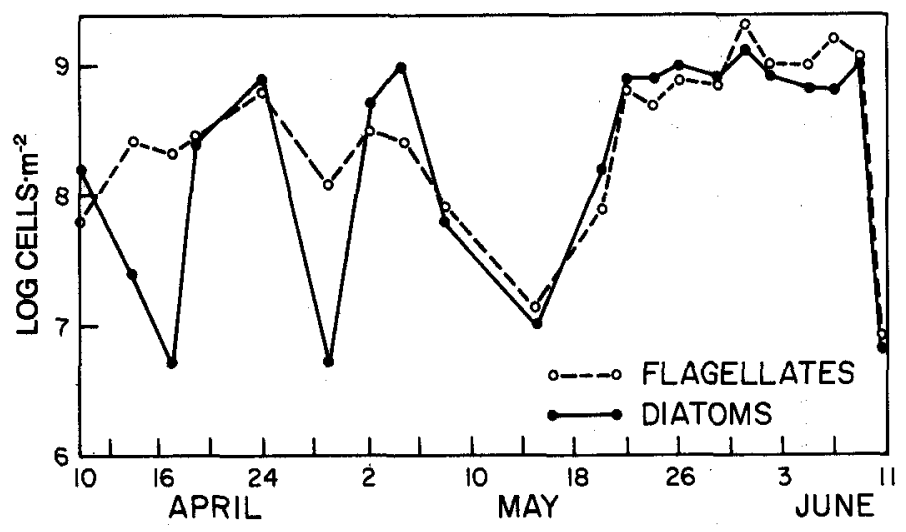

FIG. 4. Concentrations of diatoms and flagellates $\left(\log\right.$ cells $\left.\cdot \mathrm{m}^{-2}\right)$ in the ice, spring 1980.

comprised primarily of pennate diatoms with low numbers of centric diatoms, dinoflagellates, and other flagellates. Microflagellates were by far the most numerous organisms in the water column, exceeding the concentration of diatoms by an order of magnitude (Fig. 5), but the microflagellates were much smaller in size than the diatoms. The microflagellates were apparently not photosynthetic because cell numbers remained nearly constant and did not reflect changes in primary productivity or chlorophyll $a$.

Cell concentrations in the ice were variable, fluctuating between ca. $1 \times 10^{7}$ and ca. $1 \times 10^{9}$ cells $\cdot \mathrm{m}^{-2}$ from April 
TABLE 3. Relative abundance and distribution through time of microalgae species from ice cores collected by divers off Narwhal Island, spring Narwhal Island, spring 1980, and from one core collected with a SIPRE corer in November 1980

\begin{tabular}{|c|c|c|c|c|c|c|c|c|c|c|c|c|c|c|c|c|c|c|c|c|c|c|}
\hline \multirow[b]{2}{*}{ Taxon } & \multicolumn{6}{|c|}{ Apr } & \multicolumn{10}{|c|}{ May } & \multicolumn{4}{|c|}{ Jun } & \multicolumn{2}{|r|}{ Nov } \\
\hline & 10 & 14 & 17 & 19 & 24 & 29 & 2 & 5 & 8 & 15 & 20 & 22 & 24 & 26 & 29 & 31 & 2 & 5 & 7 & 9 & 11 & 9 \\
\hline \multicolumn{23}{|l|}{ Pennate Diatoms } \\
\hline Achnanthes taeniata Grunow & $\mathbf{P}$ & & & & & & & & & & & $\mathrm{O}$ & 0 & & & $\mathbf{P}$ & $\mathrm{O}$ & $x$ & O & 0 & & $\mathbf{P}$ \\
\hline \multicolumn{23}{|l|}{ Amphiprora alata (Ehrenberg) Kützing } \\
\hline Amphiprora kjellmanii Cleve & $\mathbf{P}$ & $\mathbf{P}$ & & $\mathbf{P}$ & & & & & & & & & & & & & & & & & & $P$ \\
\hline \multicolumn{23}{|l|}{ Amphiprora paludosa $\mathrm{v}$. hyperborea } \\
\hline (Grunow) Cleve & & & & & & & & & & $\mathbf{P}$ & $\mathbf{P}$ & $\mathbf{P}$ & $\mathbf{P}$ & $\mathbf{P}$ & $\mathbf{P}$ & & & & $\mathbf{P}$ & & & $\mathbf{P}$ \\
\hline Amphora ocellata Donkin & & & & & & & & & $\mathbf{O}$ & & $\mathbf{x}$ & $\mathbf{P}$ & 0 & $\mathrm{X}$ & $\mathrm{X}$ & 0 & $\mathrm{O}$ & $\mathbf{P}$ & 0 & 0 & 0 & \\
\hline \multicolumn{23}{|l|}{ Cylindrotheca closterium (Ehrenberg) } \\
\hline Reimann \& Lewin & $\mathbf{P}$ & & $\Delta$ & & $\mathbf{P}$ & & $\mathbf{P}$ & $\mathbf{P}$ & $\mathbf{P}$ & $\mathbf{P}$ & $\mathrm{O}$ & $\mathbf{O}$ & o & $\mathrm{O}$ & $\mathbf{X}$ & $\mathbf{X}$ & $\mathrm{O}$ & $\mathbf{x}$ & $\mathbf{x}$ & $\mathrm{O}$ & 0 & $\mathbf{P}$ \\
\hline Eunotia sp. & $\mathbf{P}$ & & & & & & & & & & & & & & & & & & & O & & \\
\hline Fragilaria sp. & & & & & & & & & & & $\mathbf{P}$ & & $\mathbf{P}$ & & & $\mathbf{O}$ & & & O & & $\mathbf{P}$ & $\mathbf{P}$ \\
\hline Gomphonema exiguum v. arctica Grunow & $\mathbf{0}$ & o & $\mathbf{X}$ & O & $\mathbf{O}$ & & $\mathbf{P}$ & $\mathbf{P}$ & $\mathbf{P}$ & $\mathrm{O}$ & $\mathrm{P}$ & $\mathbf{P}$ & $\mathrm{P}$ & $\mathbf{P}$ & $\mathbf{P}$ & $\mathrm{P}$ & $\mathrm{O}$ & $\mathbf{P}$ & $\mathrm{P}$ & $\mathrm{O}$ & 0 & $\mathbf{P}$ \\
\hline Gyrosigma fasciola (Ehrenberg) Cleve & $\mathbf{P}$ & & & & & & & & & & & $\mathbf{P}$ & $\mathbf{P}$ & $\mathbf{P}$ & $\mathbf{P}$ & $\mathbf{P}$ & & & $\mathbf{P}$ & $\mathbf{P}$ & & \\
\hline Gyrosigma-Pleurosigma spp. & $\mathbf{O}$ & $\mathbf{P}$ & & $\mathbf{0}$ & $\mathbf{O}$ & & $\mathbf{P}$ & $\mathbf{P}$ & $\mathbf{P}$ & $\mathbf{P}$ & $\mathbf{P}$ & 0 & 0 & 0 & $\mathbf{P}$ & $\mathbf{P}$ & $\mathbf{P}$ & $\mathbf{P}$ & $\mathbf{P}$ & $\mathbf{P}$ & $\mathbf{P}$ & $\mathbf{P}$ \\
\hline Licmophora spp. & $\mathrm{o}$ & $\mathrm{x}$ & & $\mathrm{O}$ & o & $\mathrm{O}$ & $\mathbf{P}$ & $\mathbf{P}$ & $\mathbf{P}$ & $\mathrm{O}$ & $\mathbf{P}$ & $\mathbf{P}$ & $\mathbf{P}$ & $\mathbf{P}$ & $\mathbf{P}$ & $\mathbf{P}$ & & $\mathbf{P}$ & $\mathbf{P}$ & 0 & & \\
\hline Navicula bolleana (Grunow) Cleve $c f$. & $\mathbf{P}$ & $\mathbf{O}$ & & o & $\mathbf{P}$ & o & $\mathbf{P}$ & $\mathbf{P}$ & $\mathbf{P}$ & 0 & & $\mathbf{P}$ & $\mathbf{P}$ & & & $\mathbf{P}$ & $\mathrm{O}$ & $\mathbf{0}$ & $\mathbf{P}$ & 0 & $\mathrm{O}$ & \\
\hline $\begin{array}{l}\text { Navicula directa (W. Smith) Ralfs in Pritchard } \\
\text { Navicula kjellmanii Cleve }\end{array}$ & $\mathbf{P}$ & & & & & & $\mathbf{P}$ & $\mathrm{O}$ & $\mathrm{O}$ & O & $\mathrm{o}$ & $\mathbf{O}$ & $\mathrm{x}$ & 0 & o & $\mathrm{x}$ & $\mathrm{O}$ & $\Delta$ & $\begin{array}{l}X \\
P\end{array}$ & $\Delta$ & $\mathrm{O}$ & $\mathbf{P}$ \\
\hline Navicula maculosa Donkin & $\mathbf{P}$ & & & & & & & & & & & & $\mathbf{P}$ & & $\mathbf{P}$ & $\mathbf{P}$ & $\mathbf{P}$ & $\mathbf{P}$ & $\mathbf{P}$ & $\mathbf{P}$ & & \\
\hline Navicula marina Ralfs & $\mathbf{P}$ & $\mathrm{X}$ & $\mathrm{O}$ & $\mathbf{P}$ & $\mathbf{P}$ & & $\mathbf{P}$ & $\mathbf{P}$ & $\mathbf{P}$ & $\mathbf{P}$ & $\mathbf{P}$ & $\mathbf{P}$ & $\mathbf{P}$ & $\mathbf{P}$ & & $\mathrm{P}$ & & $\mathbf{P}$ & $\mathrm{P}$ & $\mathbf{P}$ & $\mathbf{P}$ & \\
\hline Navicula pelagica Cleve & & & & & & & & & $\mathbf{P}$ & & & & & & & & & & & & & $\mathbf{P}$ \\
\hline Navicula spicula (Hickie) Cleve & $\mathrm{O}$ & & & 0 & o & $\mathrm{o}$ & $\Delta$ & $\mathrm{o}$ & 0 & 0 & $\mathbf{X}$ & 0 & $\Delta$ & $\Delta$ & $\Delta$ & $\Delta$ & $\mathbf{O}$ & $\mathrm{x}$ & $\mathrm{O}$ & $\mathrm{O}$ & 0 & $\mathbf{P}$ \\
\hline Navicula transitans Cleve & $\mathbf{P}$ & $\mathbf{O}$ & & $\mathbf{P}$ & $\mathbf{P}$ & & & & $\mathbf{P}$ & 0 & $\mathrm{O}$ & $\mathbf{O}$ & $\mathrm{O}$ & $\mathrm{X}$ & $\vec{\Delta}$ & $\overline{\mathrm{O}}$ & $\mathbf{O}$ & 0 & O & $\mathbf{X}$ & $\mathrm{X}$ & $\mathbf{P}$ \\
\hline Navicula trigonocephala Cleve & $\mathbf{P}$ & O & 0 & $\mathbf{P}$ & $\mathbf{P}$ & & $\mathbf{P}$ & $\mathbf{P}$ & & & $\mathbf{P}$ & 0 & $\mathbf{P}$ & $\mathrm{P}$ & & $\mathbf{P}$ & $\mathbf{P}$ & $\mathbf{P}$ & $\mathbf{P}$ & $\mathbf{P}$ & & \\
\hline Navicula valida v. minuta Cleve & & 0 & & & $\mathbf{P}$ & & $\mathbf{P}$ & & & 0 & $\mathbf{P}$ & & $\mathbf{P}$ & $\mathbf{P}$ & $\mathbf{P}$ & $\mathbf{P}$ & $\mathbf{P}$ & $\mathbf{P}$ & $\mathbf{P}$ & $\mathbf{P}$ & 0 & \\
\hline Navicula sp. A & $\mathbf{P}$ & & & & $\mathbf{P}$ & & & & & & $\mathbf{P}$ & & & & & $\mathbf{P}$ & & & & & & \\
\hline Nitzschia angularis W. Smith & & & & & & & & & & & & & $\mathbf{P}$ & $\mathbf{P}$ & 0 & $\mathrm{P}$ & $\mathbf{P}$ & & & & & \\
\hline Nitzschia cylindrus (Grunow) Hasle & $\Delta$ & $\Delta$ & $\mathbf{X}$ & $\Delta$ & $\Delta$ & $\mathbf{x}$ & $\Delta$ & $\Delta$ & $\Delta$ & $\Delta$ & $\Delta$ & $\Delta$ & $\Delta$ & $\Delta$ & $\Delta$ & $\Delta$ & $\Delta$ & $\mathbf{x}$ & $\mathrm{O}$ & $\mathbf{X}$ & $\Delta$ & $\Delta$ \\
\hline Nitzschia frigida Grunow & $\bar{\Delta}$ & $\overline{0}$ & & $\overline{\mathbf{P}}$ & $\bar{\Delta}$ & & $\vec{\Delta}$ & $\vec{X}$ & $\Delta$ & $\vec{X}$ & $\vec{\Delta}$ & $\vec{X}$ & & $\mathrm{O}$ & $\mathbf{0}$ & 0 & $\vec{\Delta}$ & 0 & $\Delta$ & $\Delta$ & & $\vec{P}$ \\
\hline Nitzschia seriata Cleve & & & & & & & & & & & & & & & & & & & & & & O \\
\hline Nitzschia sigma (Kützing) W. Smith cf. & & & & & & & & & & & & & & $\mathbf{P}$ & & $\mathbf{P}$ & $\mathbf{P}$ & & & $\mathbf{P}$ & & \\
\hline
\end{tabular}


TABLE 3 continued

\begin{tabular}{llllllllllllllllllllllll} 
Taxon & \multicolumn{1}{c}{ Apr } & \multicolumn{1}{c}{ May } & \multicolumn{1}{c}{ Jun } \\
\hline
\end{tabular}

Nitzschia sigmoidea (Nitzsch) W. Smith

Nitzschia sp. A

Nitzschia sp. B

Pinnularia quadratarea (A. Schmidt) Cleve

Pinnularia quadratarea $\mathrm{v}$. kerguelensis (Cleve \& Grunow) Cleve

Pinnularia quadratarea $\mathrm{v}$, theelii (Cleve) Cleve

Pseudonitzschia delicatissima (Cleve) Heiden

Stauroneis quadripedis (Cleve-Euler) Hendey

Synedra spp.

Thalassiothrix spp.

Tropidoneis sp.

Unidentified pennate diatoms

Centric Diatoms

Chaetoceros gracilis Schütt

Chaetoceros septentrionalis Østrup

Chaetoceros spp.

Thalassiosira gravida Cleve

Dinoflagellates

Amphidinium sp.

Gymnodinium sp.

Protoperidinium grenlandicum (Woloszynska) Balech

Unidentified dinoflagellates

Flagellates

Cryptomonad spp.

Dinematomonas litorale (Perty) Silva

Eutreptiella sp.

(a)

Urceolus sp.

Unidentified euglenoid sp.

Platymonas spp.

Unidentified flagellates $(<6 \mu \mathrm{m})$

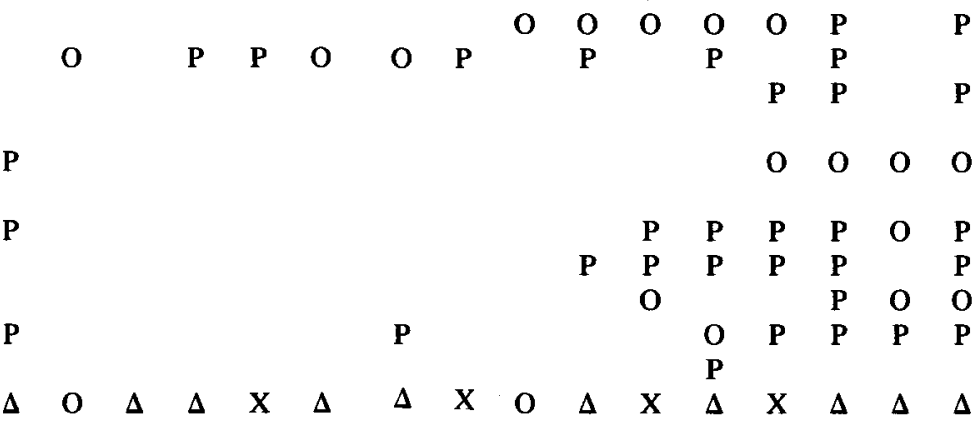

$\begin{array}{lllll}\mathbf{P} & & & \mathbf{P} & \\ \mathbf{P} & & \mathbf{P} & & \\ \mathbf{P} & \mathbf{P} & & & \end{array}$

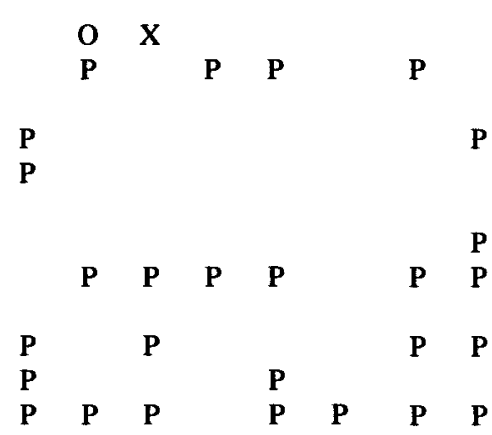

$\begin{array}{lllll}\mathbf{O} & \mathbf{P} & \mathbf{P} & \mathbf{O} & \mathbf{O} \\ & & \mathbf{P} & \mathbf{P} & \\ & \mathbf{P} & \mathbf{P} & \mathbf{P}\end{array}$

$\begin{array}{llllll}O & O & O & O & P\end{array}$

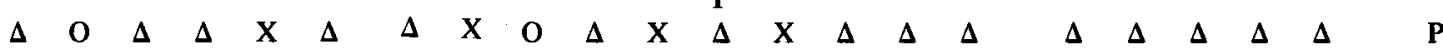

$\begin{array}{lllllllllll}\mathbf{P} & \mathbf{P} & \mathbf{P} & \mathbf{P} & \mathbf{P} & \mathbf{P} & \mathbf{P} & \mathbf{P} & \mathbf{P} & \mathbf{P} & \mathbf{P}\end{array}$

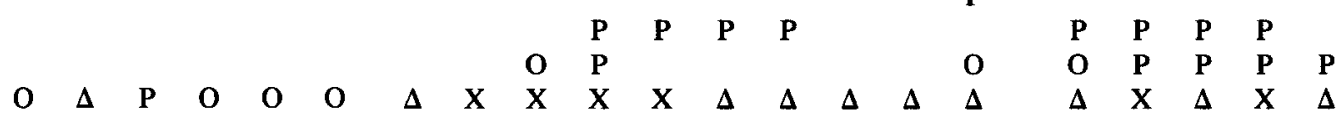

$\begin{array}{lllll} & \mathrm{X} & \Delta & \mathrm{X} & \Delta\end{array}$

$\mathrm{P}=$ present $(<1 \%) ; \mathrm{O}=$ common $(1-5 \%) ; \mathrm{X}=$ abundant $(5-10 \%) ; \Delta=$ dominant $(>10 \%)$ 


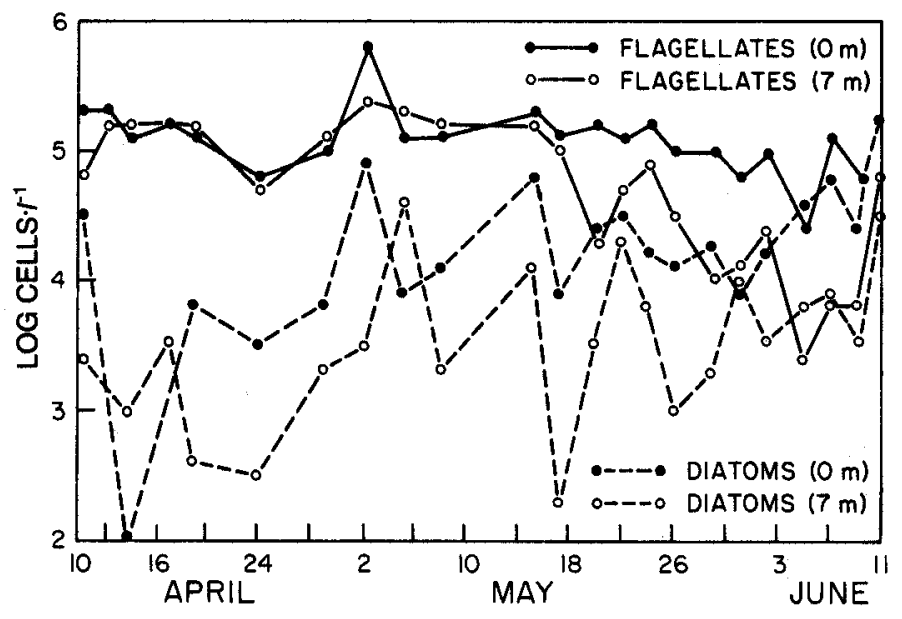

FIG. 5. Concentrations of diatoms and flagellates $\left(\log\right.$ cells $\left.\cdot l^{-1}\right)$ in the water column at 0 and $7 \mathrm{~m}$, spring 1980 .

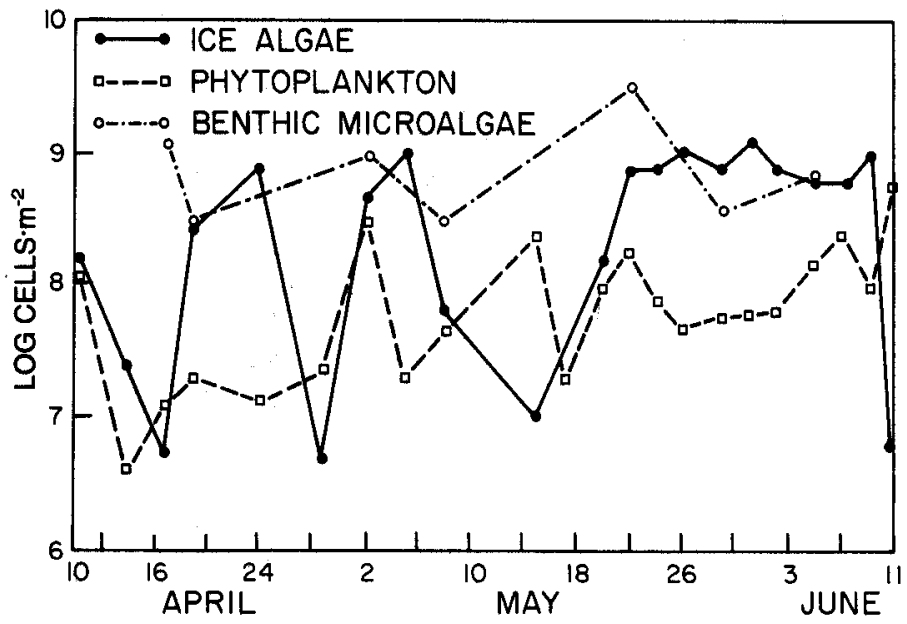

FIG. 6. Concentration of diatoms $\left(\log\right.$ cells $\left.\cdot \mathrm{m}^{-2}\right)$ in the ice, water column, and benthos, spring 1980 .

to mid-May (Fig. 6). Samples collected after 20 May were less variable, $6.6 \times 10^{8}-1.2 \times 10^{9}$ cells $\cdot \mathrm{m}^{-2}$, suggesting a more uniform distribution during the height of the bloom.

The concentration of cells in the water column was generally at least an order of magnitude lower than that found in either the ice or benthos, averaging ca. $1 \times 10^{4}$ cells $\cdot l^{-1}$ at the surface and $1 \times 10^{8}$ cells $\cdot \mathrm{m}^{-2}$ for the entire water column. Cell numbers fluctuated during the April to mid-May period and stabilized during the ice algal bloom (Fig. 6).

Seven benthic samples were analyzed, corresponding to the highest and lowest levels of chlorophyll $a$. Cell numbers correlated well with the chlorophyll $a$ values and were as high as those found in the ice, ranging from ca. $3 \times 10^{8}-3 \times 10^{9}$ cells $\cdot \mathrm{m}^{-2}$, but average cell size in the benthos was considerably smaller than that of diatoms found in the ice.
Fifty-five taxa, including 39 species or genera of pennate diatoms, four centric diatoms, three dinoflagellates, and six flagellates, were identified from ice cores (Table 3 ). The ice algal community was dominated by pennate diatoms with Nitzschia cylindrus accounting for $47 \%$ of all diatoms. Other numerically important pennate diatoms included Amphora ocellata, Cylindrotheca closterium, Navicula directa, $N$. transitans, and Nitzschia frigida. Centric diatoms were represented by few species and in low numbers. Thalassiosira gravida was most common, occurring in onethird of the samples. Chaetoceros septentrionalis was found once and other small Chaetoceros spp., $<10 \mu \mathrm{m}$, were present in three instances.

Dinoflagellates, predominantly unidentified athecate forms, were found in low numbers. Protoperidinium grenlandicum, Amphidinium sp., and Gymnodinium sp. were also present. Unidentified flagellates, $<6 \mu \mathrm{m}$ in diameter, were often the dominant organisms in the ice. Other flagellates were Platymonas sp., Cryptomonas spp., Dinematomonas litorale, Eutreptiella sp., Urceolus sp., and an unidentified euglenoid.

Changes in community structure and composition occurred during the bloom. From April to mid-May, species diversity was relatively low and was inversely related to cell numbers, with changes in diversity largely due to changes in the relative percentage by cell number of $\mathrm{Nit}$ zschia cylindrus. Diversity increased in late May when standing stocks were high, and Nitzschia cylindrus became less dominant with cells often appearing unhealthy. Both $N$. cylindrus and another dominant species, Navicula spicula, were parasitized by chytrids. Several species that had not been identified previously or had occurred rarely became common, including Achnanthes taeniata, Amphora ocellata, Cylindrotheca closterium, Navicula directa, Nitzschia sp. A, Pinnularia quadratarea var. kerguelensis, Synedra sp., and Thalassiothrix sp.

Fifty-seven taxa, including 35 species, were identified in the water column samples (Table 4). These species were predominantly the same as those that occurred in the ice, with pennate diatoms being the dominant group. Unidentified flagellates, $<6 \mu \mathrm{m}$ in diameter, were also abundant. Only five species were identified from the water column that were not found in the ice, including the centric diatoms Chaetoceros gracilis, Cyclotella sp., Leptocylindrus sp. and Melosira juergensii, and the dinoflagellate Prorocentrum sp.

Most of the cells found in the water column appeared to have originated in the ice. About $50 \%$ of cells in the samples were empty frustules, which were not included in the cell counts. Many cells appeared to be unhealthy, and were often heavily parasitized. Nitzschia cylindrus was present in low numbers during April and became dominant during May and early June. In the water column, cells of this species did not appear to be healthy and had probably fallen from the ice. 
Seventeen taxa, including 10 species, were identified from the benthos (Table 5). An additional 12 taxa with eight species were identified from empty frustules. Probably more species were present, but were not identified. The benthic microalgal community consisted almost exclusively of pennate diatoms. A single resting spore of Chaetoceros $\mathrm{sp}$. was the only centric diatom and Dinematomonas litorale was the only flagellate identified.

Although we were unable to identify the majority of the species present, they were clearly not the same species found in the ice or water column. Cylindrotheca closterium, Navicula cancellata, $N$. directa, $N$. spicula, $N$. transitans var. derasa, Nitzschia angularis, and $N$. cylindrus occurred in both the ice and sediments, but comprised a small fraction of the cells present in the sediments. Nitzschia cylindrus, the dominant species of the ice and water column, was represented by a single pair of cells near the end of the ice algal bloom. They appeared to be unhealthy and had probably fallen from the ice. All of the taxa represented by empty frustules were members of the ice algal community and probably originated there.

The concentrations of inorganic plant nutrients are given in Table 2. Data from ice cores should be considered as minimum values because they were obtained from melted cores that were diluted by an unknown amount from the melting ice.

Nitrate in the water column was near $10 \mu \mathrm{g}$-at $\cdot l^{-1}$ throughout the study period. This is comparable to levels found during the winter near Barrow (Matheke, 1973) and near Prudhoe Bay (Horner et al., 1974), but is considerably higher than in samples collected in Stefansson Sound in May 1979 where values ranged from $1.5 \mu \mathrm{g}$-at $\cdot l^{-1}$ at the surface to $4.5 \mu \mathrm{g}$-at $\cdot l^{-1}$ at $4 \mathrm{~m}$.

Nitrate concentrations in the ice were approximately equal to surface water levels from April to mid-May. The concentration increased to $15-20 \mu \mathrm{g}$-at $\cdot l^{-1}$ for two weeks during the peak of the ice algal bloom, and then declined to previous levels. The source of this nitrate is not known, but may have resulted from brine drainage or microbial activity (Schell, 1974).

Nitrite concentrations were low and remained nearly constant throughout the study period. Ammonia was highest in the ice, ca. $1.2 \mu \mathrm{g}$-at $\cdot l^{-1}$, and lowest in water from $7 \mathrm{~m}$, $0.03 \mu \mathrm{g}$-at $\cdot l^{-1}$. The ammonia concentration increased in the ice during the peak of the bloom with high values, $4.33 \mu \mathrm{g}$-at $\cdot l^{1}$, near the end of the bloom.

Phosphate concentrations in the ice and water column were generally ca. $1.5 \mu \mathrm{g}$-at $\cdot l^{-1}$, which is similar to winter levels reported from Barrow (Matheke, 1973) and Prudhoe Bay (Horner et al., 1974). Several anomalous peaks in phosphate concentration were seen, but we have no explanation for them. Silicate concentrations were nearly constant, averaging $22 \mu \mathrm{g}$-at $\cdot l^{-1}$, in the ice and surface water and slightly higher, $24 \mu \mathrm{g}$-at $\cdot l^{-1}$, at $7 \mathrm{~m}$.

Salinity was near $34.5 \%$ at the surface and $35.5 \%$ at $7 \mathrm{~m}$ (Table 2). Salinity dropped ca. $1 \%$ o during the last half of
May, possibly because of overflow from the Sagavanirktok River. The water column became stratified with a $10 \%$ difference between the surface and $7 \mathrm{~m}$ in June when the ice started to melt. Salinity in the ice was variable, probably because of melting ice in the core samples.

Light penetrating the ice and reaching the top of the algal layer fluctuated between 0.5 and $1.5 \%$ of surface light, or about 5 and $18 \mu \mathrm{E} \cdot \mathrm{m}^{-2} \cdot \mathrm{sec}^{-1}$, during the period of snow cover. Light levels increased sharply, fluctuating between 1.4 and $4 \%$ of surface values $\left(6\right.$ and $19 \mu \mathrm{E} \cdot \mathrm{m}^{-2}$ $\cdot \mathrm{sec}^{-1}$ ) after the snow cover melted on 29 May. Light beneath the ice did not generally increase in response to decreasing snow cover because of the shading effect of the growing ice algal layer. Light reaching the benthos was low, remaining near $0.2 \%$ of the surface value, or ca. $2 \mu \mathrm{E} \cdot \mathrm{m}^{-2} \cdot \mathrm{sec}^{-1}$.

\section{DISCUSSION}

The annual cycle of ice algae, phytoplankton, and benthic microalgae is shown in Figure 7. Microalgae are present in the ice as soon as it forms in the fall. Microflagellates are usually the most abundant organisms, but a few pennate diatoms may also be present (Horner, 1976). The origin of the cells is not known. Few species of ice algae are members of the fall phytoplankton community, which is dominated by centric diatoms (Horner, 1969), rather than the flagellates and pennate diatoms found in the ice. It is possible that ice algae species are present in the water column in low numbers and are not collected by conventional sampling techniques, but once trapped in the ice, natural selection favours species adapted to the ice habitat.

Newly formed sea ice may be seeded from ice algae still associated with drifting pack ice that persists throughout the summer, but it is not known if cells remain viable in the drifting pack ice as late as freeze-up. Another possible source of seed stock may be sediments that become resuspended during the fall storms in nearshore areas. Although some species are common to both habitats, many species found in the ice, including the most abundant ice species, are not found in the sediments (Matheke and Horner, 1974) although they may be rare or not detected.

Growth of the diatoms in the ice in fall probably continues until mid-November when light becomes limiting, although few reports are available to confirm this. In the Eskimo Lakes region of arctic Canada, in late November, Hsiao (1980) found a layer of ice algae concentrated near the bottom of sea ice $50 \mathrm{~cm}$ thick that contained ca. $4.9 \times$ $10^{5}$ cells $\cdot \mathrm{m}^{-3}$ (ca. $3.9 \times 10^{3}$ cells $\cdot \mathrm{m}^{-2}$ ). In the western Beaufort Sea, a core collected in early November from our study site off Narwhal Island contained a rich algal layer in the bottom of the ice (Schell, pers. comm.) with diatom concentrations of $1.8 \times 10^{8}$ cells $\cdot \mathrm{m}^{-2}$, comparable to levels found during the 1980 spring bloom. The cells were healthy and the species composition was similar to that found in 


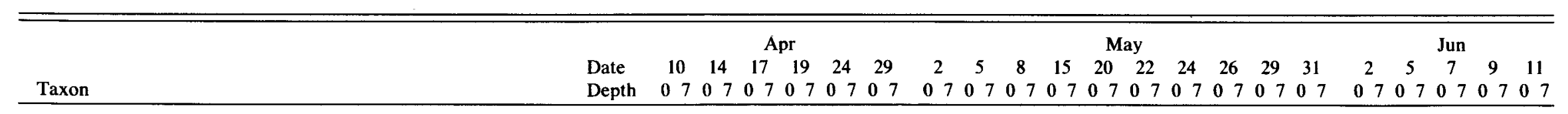

\section{Pennate Diatoms}

Achnanthes taeniata Grunow

Achnanthes sp.

Amphiprora paludosa v. hyperborea (Grunow) Cleve

Amphora ocellata Donkin

Amphora sp.

Cylindrotheca closterium (Ehrenberg) Reimann \& Lewin

Gomphonema exiguum v. arctica Grunow

Depth $\quad \begin{array}{llllllllllllllllllllllllllllllllllllllllll} & 7 & 0 & 7 & 0 & 7 & 0 & 7 & 0 & 7 & 0 & 7 & 0 & 7 & 0 & 7 & 0 & 7 & 0 & 7 & 0 & 7 & 0 & 7 & 0 & 7 & 0 & 7 & 0 & 7 & 0 & 7 & 0 & 7 & 0 & 7 & 0 & 7 & 0 & 7 & 0 & 7\end{array}$

Gomphonema kamtschaticum Grunow

Gyrosigma fasciola (Ehrenberg) Cleve

Gyrosigma-Pleurosigma spp.

Licmophora spp.

Navicula bolleana (Grunow) Cleve $c f$.

Navicula directa (W. Smith) Ralfs in Pritchard

Navicula kjellmanii Cleve

Navicula lyroides Hendey

Navicula maculosa Donkin

Navicula marina Ralfs

Navicula pelagica Cleve

Navicula spicula (Hickie) Cleve

Navicula transitans v. derasa (Grunow) Cleve

Navicula trigonocephala Cleve

Navicula valida Cleve

Navicula sp. A

Nitzschia angularis W. Smith

Nitzschia cylindrus (Grunow) Hasle

Nitzschia frigida Grunow

Nitzschia seriata Cleve

Nitzschia sigma (Kützing) W. Smith $c f$.

Nitzschia sigmoidea (Nitzsch) W. Smith

Nitzschia sp. A

Nitzschia sp. B

Pinnularia quadratarea v. kerguelensis (Cleve \& Grunow) Cleve

Pinnularia quadratarea $\mathrm{v}$, theelii (Cleve) Cleve

Pseudonitzschia delicatissima (Cleve) Heiden

Rhoiconeis sp.

Stauroneis quadripedis (Cleve-Euler) Hendey

Stauroneis sp.

Thalassiothrix spp.

Unidentified pennate diatoms

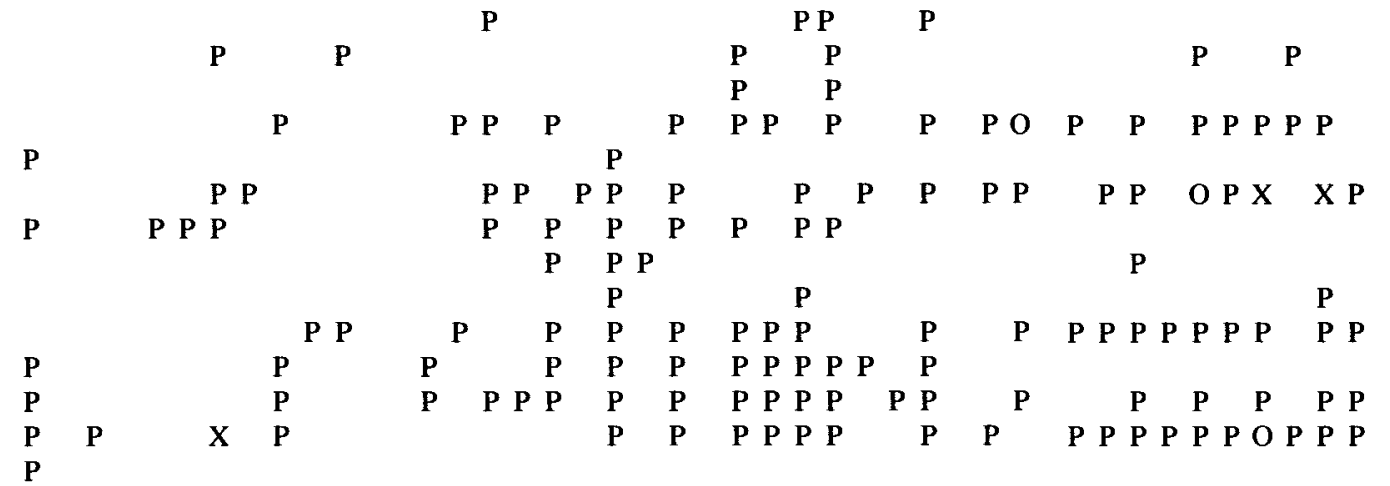

Chaetoceros gracilis Schütt

Chaetoceros septentrionalis $\emptyset$ strup

$\mathbf{P}$

$\mathbf{P} \mathbf{P} \mathbf{P}$

P P P

$\mathbf{P} \mathbf{P} \quad \mathbf{P}$

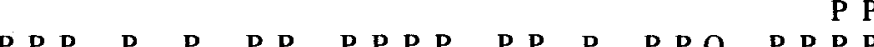
$\begin{array}{lllllllllllll}\text { P P P P P } & \text { P P } & \text { P P } & \text { P } & \text { P } & \text { P }\end{array}$ $\begin{array}{llll}P & P & P\end{array}$

$\mathbf{P} \quad \mathbf{P}$ P P

$P$
$P$ $P$

$\mathbf{P}$

P P P

$\Delta \mathrm{PP} \Delta \Delta \quad \Delta \mathrm{P} \Delta \mathrm{X} \Delta \Delta \Delta \mathrm{P} \Delta \mathrm{PO}$

P P

P P P

P P

X

$P$
$P$

$P$ P P O P P

$\begin{array}{ll}\mathbf{P} & \mathbf{P}\end{array}$

P O

P P P P

$\begin{array}{ll} & \text { P } \\ \text { P } & \\ \text { P } & \text { P } \\ \text { P P }\end{array}$

$\begin{array}{llll} & & & \mathbf{P} \\ & \mathbf{P} & \mathbf{P} & \mathbf{P} \mathbf{P}\end{array}$

$\mathbf{P}$

$\mathbf{P}$

$\begin{array}{lcccc} & \text { P } & \text { P P P P } & \text { P P } \\ \text { P P P } & \text { P P P P P P D O } & \text { P P P P P P P P } & \text { X X P P }\end{array}$
$\begin{array}{lllll}\mathbf{P} & \mathbf{P} & \underset{\mathbf{P}}{\mathbf{P}} \mathbf{P} & \mathbf{P} & \mathbf{P} \mathbf{P}\end{array}$

P P 


\begin{tabular}{|c|c|c|c|c|c|c|c|c|c|c|c|c|c|c|c|c|c|c|c|c|}
\hline \multirow[b]{2}{*}{ Taxon } & \multirow[b]{2}{*}{$\begin{array}{l}\text { Date } \\
\text { Depth }\end{array}$} & \multicolumn{5}{|c|}{ Apr } & \multicolumn{9}{|c|}{ May } & \multicolumn{5}{|c|}{ Jun } \\
\hline & & $\begin{array}{c}10 \\
07\end{array}$ & 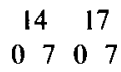 & $\begin{array}{r}19 \\
07\end{array}$ & $\begin{array}{c}24 \\
07\end{array}$ & $\begin{array}{c}29 \\
07\end{array}$ & $0^{2} 70$ & $0^{5} 70^{8}$ & 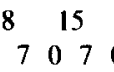 & $\begin{array}{c}20 \\
07\end{array}$ & $\begin{array}{l}22 \\
07\end{array}$ & $\begin{array}{c}24 \\
07\end{array}$ & $\begin{array}{c}26 \\
07\end{array}$ & $\begin{array}{c}29 \\
07\end{array}$ & $\begin{array}{c}31 \\
07\end{array}$ & ${ }_{07}^{2}$ & $\begin{array}{c}5 \\
07\end{array}$ & ${ }^{7} 7$ & $0^{9} 7$ & $\begin{array}{l}11 \\
07\end{array}$ \\
\hline Chaetoceros spp. & & & & & & & & & & & $\mathbf{p}$ & & & $\mathbf{P}$ & $\Delta$ & & & $\mathbf{P}$ & & \\
\hline Cyclotella sp. & & & & & & & & & & $\mathbf{P}$ & & & & & & & & & & \\
\hline Leptocylindrus sp. & & & & & & & & & $\mathbf{P}$ & & & & & & & & & & & \\
\hline Melosira juergensil Agardh & & & & & & & & & & $\mathbf{P}$ & & $\mathbf{P}$ & & & $\mathbf{P}$ & & & & & $\mathbf{P}$ \\
\hline Thalassiosira gravida Cleve & & & & & & & & & & & $\mathbf{P}$ & $\mathbf{P}$ & $\mathbf{P}$ & $\mathbf{P}$ & $\mathbf{P}$ & $\mathrm{x}$ & o & $\mathbf{P} \mathbf{P}$ & P P & P P P \\
\hline Thalassiosira spp. & & & $\mathbf{P}$ & $\mathbf{P}$ & & & & $\mathbf{P}$ & $\mathbf{P}$ & & $\mathbf{P}$ & & & & $\mathbf{P}$ & & & $\mathbf{P}$ & & $\mathrm{P}$ \\
\hline Dinoflagellates & & & & & & & & & & & & & & & & & & & & \\
\hline Amphidinium sp. & & & & & & & $\mathbf{P}$ & $\mathbf{P}$ & & $\Delta$ & 0 & & $\mathbf{P}$ & & o & $\mathrm{x}$ & $\mathbf{P}$ & $\mathbf{P}$ & & \\
\hline Dinophysis arctica Mereschkowsky & & & & & & & & & & & & & & & & & $\mathbf{P}$ & & & \\
\hline Gymnodinium sp. & & & & & & & & $\mathbf{P}$ & & & & & $\mathbf{P}$ & & & & & & & \\
\hline Prorocentrum sp. & & $\mathbf{P}$ & $\mathbf{P}$ & & & & & & & & & & & & & & $\mathbf{P}$ & $\mathbf{P}$ & & \\
\hline Protoperidinium grenlandicum (Woloszynska) Balech & & & & $\mathbf{P}$ & $\mathbf{P}$ & & & & $\mathbf{P}$ & & $\mathbf{P}$ & & & & & & $\mathbf{P}$ & $\mathbf{P}$ & $\mathbf{P}$ & $\mathbf{P} \mathbf{P}$ \\
\hline Flagellates & & & & & & & & & & & & & & & & & & & & \\
\hline Dinematomonas litorale (Perty) Silva & & & & & & & & & & & & $\mathbf{P}$ & $\mathbf{P}$ & & & & & $\mathbf{P}$ & & $\mathbf{P}$ \\
\hline Euglena sp. & & & & & & & & & & & & & & & & & $\mathbf{P}$ & $\mathbf{P}$ & $\mathbf{P}$ & \\
\hline Eutreptiella sp. & & & $\mathbf{P}$ & $\mathbf{P}$ & P $\quad 1$ & $\mathbf{P}$ & P P P & $\mathbf{P}$ & $\mathbf{P}$ & $\mathbf{P}$ & $\mathbf{P}$ & $\mathbf{P}$ & & & $\mathbf{P}$ & & & & & \\
\hline Platymonas sp. & & & & & & & & & $\mathbf{P}$ & & & $\mathbf{P}$ & & $\mathbf{P}$ & $\mathbf{P}$ & o & $\Delta$ & $\Delta$ & $\mathrm{x}$ & \\
\hline Unidentified flagellates $(<6 \mu \mathrm{m})$ & & & $\mathrm{x} 00 \mathrm{O}$ & OOP & $\mathbf{P} \mathbf{P}$ & & $0 \quad \Delta$ & $\triangle \mathrm{PXP}$ & $\mathrm{PXOX}$ & $x$ & $\mathbf{O P}$ & $x O$ & $P P C$ & OP & $O P$ & X P & $\bar{x}$ & $\bar{x}$ & $\Delta$ & $\mathbf{x}$ \\
\hline
\end{tabular}

$\mathrm{P}=$ present $(<1 \%) ; \mathrm{O}=$ common $(1-5 \%) ; \mathrm{X}=$ abundant $(5-10 \%) ; \Delta=$ dominant $(>10 \%)$ 
TABLE 5. Relative abundance and distribution through time of benthic microalgae species from seven sediment cores collected off Narwhal Island, spring 1980

\begin{tabular}{|c|c|c|c|c|c|c|c|c|c|c|c|c|c|c|c|c|c|c|c|c|c|}
\hline \multirow[b]{2}{*}{ Taxon } & \multicolumn{6}{|c|}{ Apr } & \multicolumn{10}{|c|}{ May } & \multicolumn{5}{|c|}{ Jun } \\
\hline & 10 & 14 & 17 & 19 & 24 & 29 & 2 & 5 & 8 & 15 & 20 & 22 & 24 & 26 & 29 & 31 & 2 & 5 & 7 & 9 & 1 \\
\hline \multicolumn{22}{|l|}{ Pennate Diatoms } \\
\hline Achnanthes sp. & & & & & & & $\mathrm{X}$ & & $\mathbf{P}$ & & & $\mathrm{O}$ & & & & & & & & & \\
\hline Amphora sp. & & & & & & & & & & & & & & & & & & $\mathrm{P}$ & & & \\
\hline \multicolumn{22}{|l|}{ Cylindrotheca closterium (Ehrenberg) } \\
\hline Reimann \& Lewin & & & & & & & & & & & & & & & $P$ & & & & & & \\
\hline Diploneis smithii (de Brébisson) Cleve & & & $\mathrm{X}$ & & & & & & & & & $\mathrm{O}$ & & & & & & 0 & & & \\
\hline Diploneis sp. & & & & & & & & & & & & $\mathrm{O}$ & & & & & & & & & \\
\hline \multicolumn{22}{|l|}{ *Gomphonema exiguum v, arctica Grunow } \\
\hline \multicolumn{22}{|l|}{ *Gomphonema kamtschaticum Grunow } \\
\hline \multicolumn{22}{|l|}{ * Gyrosigma fasciola (Ehrenberg) Cleve } \\
\hline \multicolumn{22}{|l|}{ *Gyrosigma-Pleurosigma spp. } \\
\hline Navicula cancellata Donkin & & & $\Delta$ & $\Delta$ & & & $\Delta$ & & $\mathrm{O}$ & & & $\mathrm{X}$ & & & $\Delta$ & & & $\Delta$ & & & \\
\hline Navicula cancellata $\mathrm{v}$. skaldensis Van Heurck & & & $\mathbf{P}$ & & & & $\mathbf{P}$ & & & & & $\mathrm{O}$ & & & & & & $\mathrm{O}$ & & & \\
\hline \multirow{2}{*}{\multicolumn{22}{|c|}{ *Navicula gracilis Kützing }} \\
\hline & & & & & & & & & & & & & & & & & & & & & \\
\hline \multicolumn{22}{|l|}{ *Navicula peregrina (Ehrenberg) Kützing } \\
\hline Navicula spicula (Hickie) Cleve & & & & & & & & & & & & & & & $\Delta$ & & & & & & \\
\hline Navicula transitans $\mathrm{v}$. derasa (Grunow) Cleve & & & $\mathbf{P}$ & $\mathbf{P}$ & & & $\mathbf{P}$ & & & & & $\mathrm{O}$ & & & & & & $\mathbf{P}$ & & & \\
\hline Nitzschia angularis $\mathbf{W}$. Smith & & & & $\mathbf{P}$ & & & & & & & & $\mathrm{P}$ & & & & & & & & & \\
\hline Nitzschia cylindrus (Grunow) Hasle & & & & & & & & & & & & & & & & & & $\mathbf{P}$ & & & \\
\hline \multicolumn{22}{|l|}{ *Nitzschia frigida Grunow } \\
\hline \multicolumn{22}{|l|}{ * Pinnularia quadratarea (A. Schmidt) Cleve } \\
\hline Stauroneis sp. & & & $\mathbf{P}$ & & & & & & & & & & & & & & & & & & \\
\hline Synedra spp. & & & & & & & & & & & & $\mathbf{P}$ & & & & & & $\mathrm{P}$ & & & \\
\hline Unidentified tube-forming species & & & & & & & & & & & & & & & & & & $\Delta$ & & & \\
\hline Unidentified pennate diatoms & & & $\Delta$ & $\Delta$ & & & $\Delta$ & & $\Delta$ & & & $\Delta$ & & & $\Delta$ & & & $\Delta$ & & & \\
\hline \multicolumn{22}{|l|}{ Centric diatoms } \\
\hline \multicolumn{22}{|l|}{${ }^{*}$ Chaetoceros spp. } \\
\hline \multirow{2}{*}{\multicolumn{22}{|c|}{$\begin{array}{l}\text { Chaetoceros } \mathrm{sp} \text {. resting spore } \\
{ }^{*} \text { Coscinodiscus radiatus Ehrenberg }\end{array}$}} \\
\hline & & & & & & & & & & & & & & & & & & & & & \\
\hline \multicolumn{22}{|l|}{ *Thalassiosira sp. } \\
\hline \multicolumn{22}{|l|}{ Flagellates } \\
\hline Dinematomonas litorale (Perty) Silva & & & & & & & & & $\mathbf{P}$ & & & & & & & & & & & & \\
\hline
\end{tabular}

$\mathrm{P}=\operatorname{present}(<1 \%) ; \mathrm{O}=$ common $(1-5 \%) ; \mathrm{X}=$ abundant $(5-10 \%) ; \Delta=$ dominant $(>10 \%) ;{ }^{*}$ indicates only empty frustules present.

TABLE 6. Annual ice algal productivity determined from ${ }^{14} \mathrm{C}$ uptake experiments and chlorophyll $a$ concentrations

\begin{tabular}{lcl}
\hline Location & $\begin{array}{c}\text { Annual Productivity } \\
\left(\mathrm{mg} \mathrm{C} \cdot \mathrm{m}^{-2}\right)\end{array}$ & \multicolumn{1}{c}{ Source } \\
\hline Davis Strait & 0.15 & Andersen (1977) \\
Barrow, Alaska & 5.0 & Alexander et al. (1974) \\
Stefansson Sound & 0.9 & Horner (1980) \\
Simpson Lagoon & $0.18^{*}$ & Schell (1980b) \\
Stefansson Sound & $1.4^{*}$ & Schell (1980b) \\
Offshore Beaufort Sea & $1.7^{*}$ & Schell (1980b) \\
Narwhal Island & 0.7 & This study \\
\hline \hline
\end{tabular}

*Estimated from chlorophyll $a$ concentrations the ice the preceding spring. It is not known whether this is a regular occurrence, how long this bloom might last, or how productive it is. An autumnal bloom has been reported to be a normal event in the Antarctic sea ice (Hoshiai, 1977).

Heterotrophy has been suggested as a mechanism by which algae survive the prolonged darkness of the arctic winter (Rodhe, 1955; Wilce, 1967; Allen, 1971), but experiments using a variety of labeled organic substrates failed to show heterotrophic growth in the dark for Antarctic (Bunt and Lee, 1972) or Arctic (Horner and Alexander, 1972) ice algae. Antia (1976) has shown that many algal species maintain viability for 5-6 mo in media free of organic substrates at temperatures ranging from $2-20^{\circ} \mathrm{C}$. Benthic species, i.e. pennate diatoms, were more resistant, 


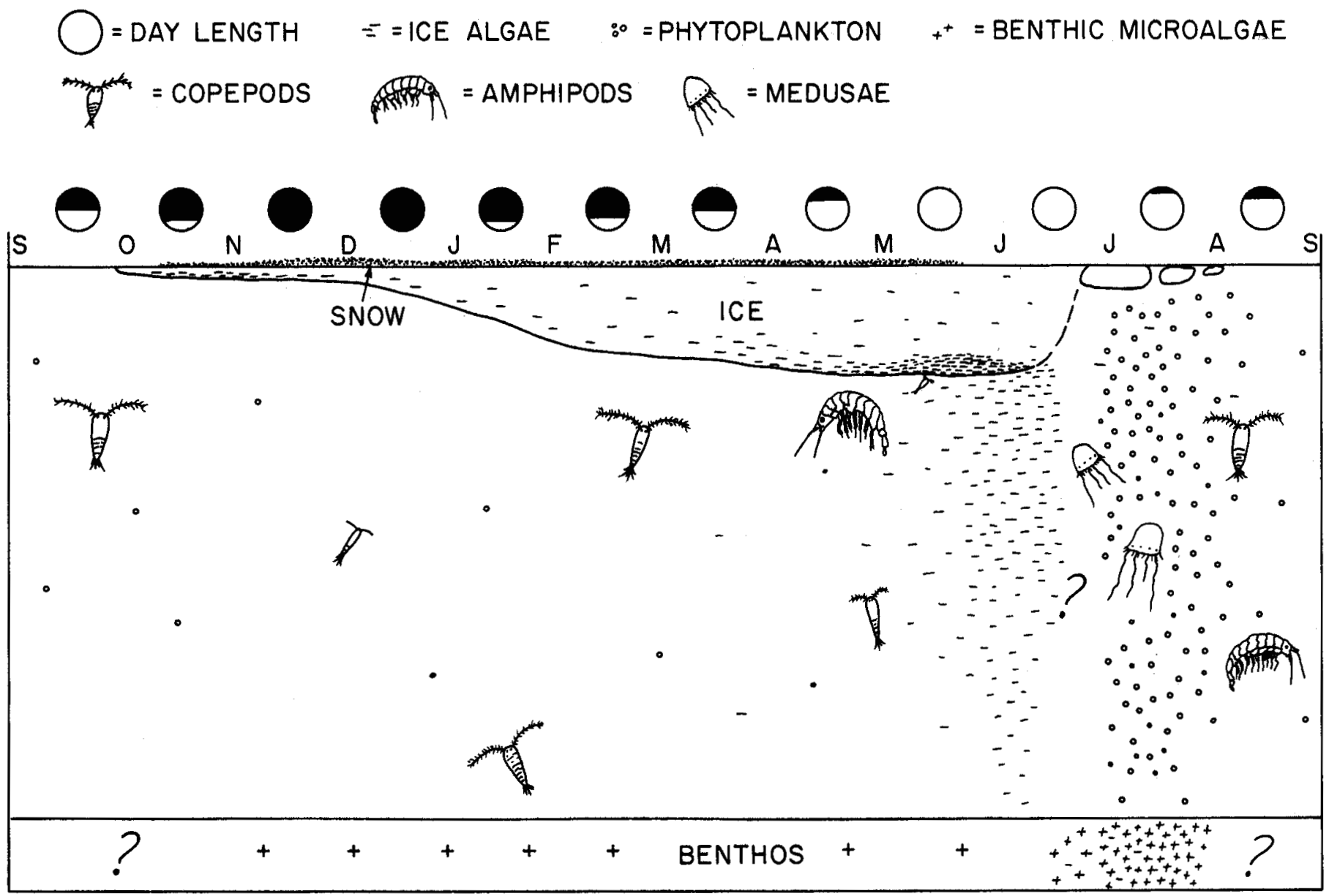

FIG. 7. Schematic representation of the annual cycles of ice algae, phytoplankton, and benthic microalgae in the nearshore area of the Beaufort Sea and Stefansson Sound.

with some remaining viable for over one year and a few species for three years of darkness. We expect that ice algae, adapted to low temperatures, would easily be able to survive the 4-5 mo period of winter darkness.

Cells are scattered throughout the ice in winter (Horner, 1976; Hsiao, 1980), but by mid-March the algae become concentrated at the bottom of the ice. It is not known how the cells become concentrated, but it may be a result of brine drainage and the active migration of algal cells through brine channels that move downward through the ice by diffusion and gravity. Brine drainage becomes more rapid as the ice warms in spring which may accelerate the transport of the algae. The algae may actively migrate as well, because many pennate diatoms are able to move with a slow, gliding movement.

Light is apparently the major factor controlling the distribution, development, and production of the ice algal community with growth of the ice algae beginning in spring in response to increasing light. In the Chukchi Sea near Barrow, productivity remained $<0.1 \mathrm{mg} \mathrm{C} \cdot \mathrm{m}^{-2} \cdot \mathrm{hr}^{-1}$ until a threshold light level was reached (Alexander et al., 1974). Above this level, 2.3 and $9.3 \mu \mathrm{E} \cdot \mathrm{m}^{-2} \cdot \mathrm{sec}^{-1}$ in successive years, production was rapid. Off Narwhal Island, produc- tivity began to increase when the light level was 7.7 $\mu \mathrm{E} \cdot \mathrm{m}^{-2} \cdot \mathrm{sec}^{-1}$.

Light may be severely limited by sediments trapped in the ice in nearshore areas. One or more layers of sediment were present in a series of ice cores collected in Stefansson Sound in early April 1980 and no algal layer was detected. In mid-May, we sampled Stefansson Sound again and found only a trace amount of chlorophyll $a$ at a time when productivity was high at Narwhal Island. This is in contrast to 1979 when the algal layer in the same area was well-developed, though patchy. Light attenuation by turbid ice is the factor controlling the development of the ice algal community in Stefansson Sound, according to Schell $(1980 a, b)$. In shallow areas, the extent of the ice algal layer, and thus spring productivity of the lagoon, is apparently determined by the distribution of sediments in the ice.

Where ice does not contain sediment, light attenuation because of snow is the prime factor controlling the distribution and productivity of ice algae. The light-attenuating property of snow is very high compared with that of clear sea ice (Thomas, 1963). We found that ca. $2 \%$ of surface light reached the algal layer when no snow was present, 
but $3-4 \mathrm{~cm}$ of snow reduced light to $1 \% ; 6 \mathrm{~cm}$ to $<0.5 \%$ and $20 \mathrm{~cm}$ to $<0.1 \%$ of the surface level. Alexander et al. (1974) found that patchy distribution of the ice algae was correlated with light attenuation due to snow, and found an inverse relation between chlorophyll $a$ and snow depth. Our transects through snow drifts off Narwhal Island showed the same relationship.

Maximum productivity off Narwhal Island occurred at light levels of $10-25 \mu \mathrm{E} \cdot \mathrm{m}^{-2} \cdot \mathrm{sec}^{-1}$. Alexander et al. (1974) found that maximum productivity near Barrow occurred at slightly higher levels, $16-65 \mu \mathrm{E} \cdot \mathrm{m}^{-2} \cdot \mathrm{sec}^{-1}$. Productivity over the entire bloom period was $0.7 \mathrm{~g} \mathrm{C} \cdot \mathrm{m}^{-2}$ off Narwhal Island compared with $5 \mathrm{~g} \mathrm{C} \cdot \mathrm{m}^{-2}$ at Barrow. In both areas, productivity increased in response to increasing light levels and maximum production occurred after the snow cover was gone. The differences in productivity may have been caused by different light levels with light being more limiting off Narwhal Island.

Nutrient concentrations at the water surface were high in spring because of vertical mixing and regeneration during winter. Nutrient levels in the ice may be even higher than at the water surface because of brine drainage and local recycling. That recycling of nutrients occurs is suggested by a pulse of nitrate during the ice algal bloom. This pulse probably resulted from nitrification by the microbial population. The ammonia concentration was also high during the bloom, which suggests heavy grazing pressure or bacterial recycling.

Surface water salinity was fairly constant at $34-35 \%$ o until early June when melting ice and river runoff caused surface salinity to drop below $25 \%$. River runoff was detected about two weeks before the ice began to melt. The algal layer began to soften and dissociate from the harder bottom ice and was easily disturbed by bubbles from the diver's breathing apparatus. Several dominant ice algal species, including Nitzschia cylindrus and Navicula spicula, appeared to be unhealthy, and productivity dropped for about a week. These events coincided with the disappearance of the snow and it is likely that increasing radiation contributed to the disintegration of the ice algal layer because of selective absorption of solar energy by the diatoms (Meguro et al., 1966, 1967).

The ice algae remained associated with the bottom ice in a loose slush layer for a week after the ice began to melt, but by 11 June no layer was visible and the water was clouded with ice algae. Microscopic examination of cells from the water column showed that they were not healthy, and primary production in the water was barely detectable.

The fate of the ice algae in Stefansson Sound and off Narwhal Island is not known. No data are available after the ice algae leave the ice and there is no information for the period of ice breakup or for the spring phytoplankton bloom. At Barrow, the ice algal bloom and the spring bloom in the water column are clearly separated both by the species present and by time. The ice community consists primarily of pennate diatoms (Horner and Alexander, 1972; Alexander et al., 1974), while the spring phytoplank- ton bloom consists primarily of centric diatoms (Horner, 1969). Only one species, Nitzschia cylindrus, is common in both the ice and water column communities. The ice algal bloom occurs in April and May, sometimes extending into early June, while the phytoplankton bloom at Barrow does not start until ice breakup is underway and light is available to the cells in the water column. In shallow, coastal waters, the phytoplankton bloom may be delayed somewhat by the low salinity of the water column caused by the melting ice.

Data presented here indicate that cells found in the water column and benthos originated in the ice. This is undoubtedly so, but cells originating in the ice and found in the water and benthos were not healthy and the relatively high productivity peak reported for the water column at the end of the ice algal bloom did not last (Fig. 2). We think that the high water column productivity peak was caused by cells just released from the ice that were marginally productive. After a short time in the water column these cells became unhealthy and were no longer productive. Reasons for this are not known, but might include senescence of the cells, higher temperatures or lower salinity of the water column, or specific adaptation to the brine cell environment.

In the Bering and Chukchi seas, Saito and Taniguchi (1978) reported "ice plankton" - species that probably grew in sea ice - in deeper water during summer, but whether these cells remain viable and, if brought back into the surface water, are able to seed new ice in the fall is not known. Hameedi (1978) also suggested that the ice algae contributed a substantial amount to the chlorophyll content of the water column in the Chukchi Sea, but neither of these authors actually sampled the sea ice and Hameedi (1978) did not determine species present in either the ice or the water column, basing his assumption only on water column chlorophyll data. Schandelmeier and Alexander (1981) compared species from ice with species found in the water column at the same time and found species common to both environments, but their ice samples were not quantitative. More information is needed before it is possible to determine the importance of ice algae to the spring bloom in the water column in all areas.

The species composition of the ice algal community off Narwhal Island and in Stefansson Sound was similar to that reported from other areas of the Arctic (Meguro et al., 1966, 1967; Horner and Alexander, 1972; Hsiao, 1980). The community was dominated by pennate diatom species, and although centric diatoms and dinoflagellates occurred, they were represented by few species and were seldom abundant. Several identifiable flagellate species were present in low numbers, while unidentified flagellates were often abundant. A single pennate diatom, Nitzschia cylindrus, accounted for nearly $50 \%$ of the population off Narwhal Island. Nitzschia frigida, Navicula directa, N. transitans, Cylindrotheca closterium, and Amphora ocellata were also numerically important species. 
About 200 diatom species have been identified from arctic sea ice, but only a few species have been reported as dominant. Of 55 species enumerated in our samples, only six species ever accounted for more than $10 \%$ of the cells counted. Horner and Alexander (1972) found that Nitzschia frigida was usually the most abundant species at Barrow, but Meguro et al. $(1966,1967)$ apparently did not find it farther offshore. It was often important in the community off Narwhal Island, in Stefansson Sound, and in the Canadian Arctic (Dunbar and Acreman, 1980; Hsiao, 1980). Navicula marina was also a prominent member of the community at Barrow and was often the most abundant species (Alexander et al., 1974), but it was never abundant off Narwhal Island.

Changes in community structure accompanied the development of the bloom off Narwhal Island. During April and early May, the community was strongly dominated by Nitzschia cylindrus, but in mid-May this species became less healthy and empty frustules were common in the ice and water column. As the relative numbers of $N$. cylindrus declined, other diatom and flagellate species that had been rare or not previously identified became common and the diversity of the community increased. An increase in standing stock (chlorophyll $a$ ) accompanied this shift in community structure.

Environmental factors may have contributed to these species changes. Light inhibition has been suggested as a factor limiting the ice algal bloom (Apollonio, 1965) and it is possible that increasing light intensity resulting from snow melt may have favored more light-adapted species. Salinity declined during the peak of the bloom, and although ice algae are known to tolerate a wide range of salinities (Grant and Horner, 1976), the specific requirements of Nitzschia cylindrus are not known and the reduced salinity may have been more favorable to the development of other species. Increasing nitrate levels may also have favored species that prefer higher nitrate concentrations.

The development of the spring ice algal bloom off Narwhal Island is similar to that reported by Alexander et al. (1974) for the Chukchi Sea near Barrow, which is the only other study to include the complete cycle of the ice algal bloom. Algal biomass (chlorophyll $a$ ) off Narwhal Island exhibited the same bimodal distribution and timing, and reached comparable peak values. An early peak occurred in late April-early May during both studies, with high values of ca. $8 \mathrm{mg}$ chlorophyll $a \cdot \mathrm{m}^{-2}$. A later and maximum peak occurred the end of May-early June with $23 \mathrm{mg} \cdot \mathrm{m}^{-2}$ reported at Barrow and $26 \mathrm{mg} \cdot \mathrm{m}^{-2}$ off Narwhal Island. Primary productivity followed similar patterns in both studies, remaining relatively low until mid-May and climbing to peak levels with a maximum during the last week of May. Total production for the bloom off Narwhal Island was about one-seventh that reported for Barrow and may have been due to lower light levels.

It is difficult to compare rates of primary productivity measured off Narwhal Island with other areas of the Arc- tic because few measurements have been made and methods generally have been different. Only the Barrow (Alexander et al., 1974), Stefansson Sound, and Narwhal Island studies have used similar in situ techniques. Andersen (1977) used a modified in situ method in the Davis Strait area and Schell (1980a, b) estimated productivity from chlorophyll $a$ measurements in Simpson Lagoon, Stefansson Sound, and offshore in the Beaufort Sea (Table 6). The highest production was from Barrow and the lowest from Davis Strait. Only the Barrow and Narwhal Island studies were done throughout the whole cycle of the ice algal bloom from April or earlier to June.

It should be stressed that primary productivity measurements of ice algae are probably minimum values. We feel that while our methods (Clasby et al., 1973; Schrader et al., 1982) were the most appropriate and the best available at the time, there are several sources of error that lead to an underestimate of productivity. Because the ice algal layer is formed of a matrix of ice crystals, it is difficult to ensure adequate mixing of the isotope throughout the sample, and due to the porous nature of the ice, an unknown amount of label may diffuse upward into the ice and be lost during incubation. These and other problems undoubtedly lead to an underestimate of primary productivity by the ice algae. The productivity of this community is therefore probably greater than our measurements indicate.

Phytoplankton was present in low numbers during the winter, with unidentified flagellates, mostly $<10 \mu \mathrm{m}$ in diameter, being the most abundant organisms. By April, diatoms were more abundant in both numbers and species, but microflagellates were still numerically dominant. Most of the diatoms were pennate species that had probably fallen out of the ice. Only a few centric species were present, with Thalassiosira gravida becoming more common late in the spring. This species is often abundant during the spring bloom in nearshore waters, but none of the other typical spring bloom species occurred during our sampling program.

Chlorophyll $a$ was low, $<0.1 \mathrm{mg} \cdot \mathrm{m}^{-3}$, during the winter, increasing to $1.4 \mathrm{mg} \cdot \mathrm{m}^{-3}$ on $11 \mathrm{June}$, the last sampling day. Pheopigments were usually high, suggesting that cells were not healthy, and microscopic examination indicated that this was the case. Primary productivity in the water column was low, usually $<0.1 \mathrm{mg} \mathrm{C} \cdot \mathrm{m}^{-3} \cdot \mathrm{hr}^{-1}$; maximum ${ }^{14} \mathrm{C}$ uptake, only $0.42 \mathrm{mg} \mathrm{C} \cdot \mathrm{m}^{-3} \cdot \mathrm{hr}^{-1}$, occurred at the surface on 7 June.

We do not know when or if a spring bloom occurs in the water column. If there is a spring bloom, it probably occurs during and just after ice breakup based on data from the Barrow area (Horner, 1969), but no data are available for the period between the end of the ice algal bloom and breakup in the nearshore Beaufort Sea. The only published summer phytoplankton data for the nearshore Beaufort Sea are Alexander (1974) and Horner et al. (1974).

The annual cycle of benthic microalgae has been documented for the nearshore area at Barrow (Matheke 
and Horner, 1974). Growth was limited during the winter by low light levels; productivity did not begin until the formation of melt ponds on the ice surface that, along with the disappearance of the ice algae, increased light transmission through the ice. Following breakup of the shorefast ice, benthic microalgae became the most important source of primary production in that nearshore ecosystem. Chlorophyll $a$ concentrations were relatively high during the winter months when primary productivity was negligible, and the community was apparently able to survive long periods of darkness. Many of the same species were found in both the bottom ice and the sediments, but some of the species in the ice, including several of the most abundant, were not found in the sediment either during or after the bloom in the ice. This suggests that ice algae probably do not contribute significantly to benthic productivity.

Our spring data agree with Matheke and Horner (1974). Benthic microalgae did not contribute significantly to primary productivity off Narwhal Island. Productivity was limited by low light levels caused by snow cover and by shading from the ice algal layer. Light levels remained low even after melt ponds formed and the ice algal layer dissipated because of shading from algae suspended in the water column. Although productivity was low, chlorophyll $a$ concentrations in the sediments were relatively high throughout the spring. Concentrations increased during maximum development of the ice algal bloom, probably from algal material falling from the ice as evidenced by high pheopigment concentrations. The benthic microalgal community contained a distinct flora, dominated by species not found in the ice algal community. Few ice algal species occurred in the sediments, and most were dead or in poor condition. The most abundant species in the ice and water column, Nitzschia cylindrus, was rarely found in the sediments. Some species, such as Navicula directa, $N$. transitans, and Cylindrotheca closterium, were members of both communities, and have been reported from the sediments and ice at Barrow (Matheke and Horner, 1974). No data are available for the benthic microalgal community after ice breakup at Narwhal Island, so we do not know if a mat of filamentous diatoms forms or if this community is an important source of primary productivity in summer.

Although we have documented the development of the ice algal bloom and the relative contributions and interrelationships of the ice algae, phytoplankton, and benthic microalgae to primary productivity during much of the winter-spring period, a number of questions remain to be answered. We do not know what happens in the period after the dissolution of the ice algal layer in early June leading up to a possible spring phytoplankton bloom after breakup. What is the fate of the ice algae once they leave the ice? Are they consumed by zooplankton? Are they incorporated into the sediments? Do many of the cells die in the low-salinity water during ice melt with rapid dissolution of the silica frustules? We assume a spring phytoplankton bloom, if one occurs, is composed of different species from those found in the ice algae and water column in winter, as is the case at Barrow. Is this really so? What triggers the bloom in the water column? When does it occur? How important are the benthic microalgae in summer? Are the benthic microalgae utilized as a food source by invertebrates? How important is the fall bloom in the ice? Is it a regular occurrence? What is the role of the microflagellates that are present in the ice and water column? Many of them are apparently not photosynthetic, but they may still be an important food source for grazers. How important are the ice fauna in controlling the ice algal bloom? And finally, because this study was done in response to the development of the oil and gas industry in the area, what will be the effects of oil, drilling muds, and other possible pollutants from this industry on these communities and how will this affect the whole Beaufort Sea ecosystem?

\section{ACKNOWLEDGEMENTS}

Winter sampling in November 1978, and February and March 1979, was done by T. Kaperak; May 1979 sampling was done by J. Hanes and R. Horner. G. F. Smith re-designed and fabricated the new ice sampler-incubation chambers; G. C. Schrader, D. Murphy, and divers R. Poirot and J. Dougherty did the field work at Narwhal Island; K. Persons, S. Petersen, and NOAA helicopter crews provided logistic support in the field; R. Atlas and P. Hill analyzed the benthic microalgae productivity samples. We benefited from discussions with A. G. Carey, Jr., J. Kern, R. E. Ruff, P. Scott, and D. M. Schell. This study was supported by the Bureau of Land Management through interagency agreement with the National Oceanic and Atmospheric Administration as part of the Alaskan Outer Continental Shelf Environmental Assessment Program.

\section{REFERENCES}

ALEXANDER, V. 1974. Primary productivity regimes of the nearshore Beaufort Sea, with reference to potential roles of ice biota. In: Reed, J.C. and Sater, J.E. (eds.). The Coast and Shelf of the Beaufort Sea. Arlington, VA: The Arctic Institute of North America. 609-632.

, HORNER, R. and CLASBY, R.C. 1974. Metabolism of arctic sea ice organisms. Institute of Marine Science, University of Alaska, Report R74-4. 120 p.

ALLEN, M.B. 1971. High-latitude phytoplankton. Annual Review of Ecology and Systematics 2:261-276.

ANDERSEN, O.G.N. 1977. Primary production associated with sea ice at Godhavn, Disko, West Greenland. Ophelia 16:205-220.

ANTIA, N.J. 1976. Effects of temperature on the darkness survival of marine microplanktonic algae. Microbial Ecology 3:41-54.

APOLLONIO, S. 1965. Chlorophyll in arctic sea ice. Arctic 18:118-122.

ATLAS, R.M. and HUBBARD, J.S. 1974. Applicability of radiotracer methods of measuring ${ }^{14} \mathrm{CO}_{2}$ assimilation for determining microbial activity in soil, including a new in situ method. Microbial Ecology $1: 145-163$.

BUNT, J.S. and LEE, C.C. 1972. Data on the composition and dark survival of four sea-ice microalgae. Limnology and Oceanography 17:458-461.

CLASBY, R.C., HORNER, R. and ALEXANDER, V. 1973. An in situ method for measuring primary productivity of arctic sea ice algae. Journal of the Fisheries Research Board of Canada 30:835-838.

DUNBAR, M.J. and ACREMAN, J. 1980. Standing crops and species composition of diatoms in sea ice from Robson Channel to the Gulf of St. Lawrence. Ophelia 19:61-72. 
GRANT, W.S. and HORNER, R. 1976. Growth responses to salinity variation in four arctic ice diatoms. Journal of Phycology 12:180-185.

HAMEEDI, M.J. 1978. Aspects of water column primary productivity in the Chukchi Sea during summer. Marine Biology 48:37-46.

HORNER, R. 1969. Phytoplankton in coastal waters near Barrow, Alaska. Unpublished Ph.D. thesis, Department of Botany, University of Washington, Seattle, Washington. 1976. Sea ice organisms. Oceanography and Marine Biology Annual Review 14:167-182. and ALEXANDER, V. 1972. Algal populations in arctic sea ice: an investigation of heterotrophy. Limnology and Oceanography $17: 454-458$

COYLE, K.O. and REDBURN, D.R. 1974. Ecology of the plankton of Prudhoe Bay, Alaska. Institute of Marine Science, University of Alaska, Report R74-2; Sea Grant Report 73-15. 78 p.

HOSHIAI, T. 1977. Seasonal changes of ice communities in the sea ice near Syowa Station, Antarctica. In: Dunbar, M.J. (ed.). Polar Oceans. Calgary, Alberta: The Arctic Institute of North America. 307-317.

HSIAO, S.I.C. 1980. Quantitative composition, distribution, community structure and standing stock of sea ice microalgae in the Canadian Arctic. Arctic 33:768-793.

MATHEKE, G.E.M. 1973. The ecology of the benthic microalgae in the sublittoral zone of the Chukchi Sea near Barrow, Alaska. Unpublished M.S. thesis, Institute of Marine Science, University of Alaska, Fairbanks, Alaska.

and HORNER, R. 1974. Primary productivity of the benthic microalgae in the Chukchi Sea near Barrow, Alaska. Journal of the Fisheries Research Board of Canada 31:1779-1786.

MEGURO, H., ITO, K. and FUKUSHIMA, H. 1966. Diatoms and the ecological conditions of their growth in sea-ice in the Arctic Ocean. Science 152:1089-1090.

1967. Ice flora (bottom type): a mechanism of primary production in polar seas and the growth of diatoms in sea ice. Arctic 20:114-133.

PAVLOU, S.P. 1972. Phytoplankton growth dynamics: chemostat methodology and chemical analysis. Department of Oceanography, University of Washington Special Report No. 52.130 p.
RODHE, W. 1955. Can plankton production proceed during winter darkness in subarctic lakes? Verhandlungen der internationalen Vereinigung für theoretische und angewandte Limnologie 12:117-122.

SAITO, K. and TANIGUCHI, A. 1978. Phytoplankton communities in the Bering Sea and adjacent seas. II. Spring and summer communities in seasonally ice-covered areas. Astarte 11:27-35.

SCHANDELMEIER, L. and ALEXANDER, V. 1981. An analysis of the influence of ice on spring phytoplankton population structure in the southeast Bering Sea. Limnology and Oceanography 26:935-943.

SCHELL, D.M. 1974. Regeneration of nitrogenous nutrients in Arctic Alaskan estuarine waters. In: Reed, J.C., and J.E. Sater. (eds.). The Coast and Shelf of the Beaufort Sea. Arlington, Virginia: The Arctic Institute of North America. 649-664.

$1980 \mathrm{a}$. Chemical overview of biological-physical process interactions. Outer Continental Shelf Environmental Assessment Program, Arctic Project Bulletin 29:25-31.

$1980 \mathrm{~b}$. Foodweb and nutrient dynamics studies in nearshore Alaskan Beaufort Sea waters. Environmental Assessment of the Alaskan Continental Shelf, Annual Reports 2:467-513.

SCHRADER, G.C., HORNER, R. and SMITH, G.F. 1982. An improved chamber for in situ measurement of primary productivity of Arctic sea ice algae. Canadian Journal of Fisheries and Aquatic Science 39:522-524,

STRICKLAND, J.D.H. and PARSONS, T.R. 1972. A Practical Handbook of Seawater Analysis. Bulletin of the Fisheries Research Board of Canada 167.310 p.

THOMAS, C.W. 1963. On the transfer of visible radiation through sea ice and snow. Journal of Glaciology 4:481-484.

UTERMÖHL, H. 1931. Neue Wege in der quantitativen Erfassung des Planktons. Verhandlungen der internationalen Vereinigung für theoretische und angewandte Limnologie 5:567-596.

WILCE, R.T. 1967. Heterotrophy in arctic sublittoral seaweeds. Botanica Marina 10:185-197. 